\title{
Agriculture in NW Iberia during the Bronze Age: A review of archaeobotanical data
}

\author{
João Pedro Tereso ${ }^{\mathrm{a}, \mathrm{b}, *}$, Ana M.S. Bettencourt ${ }^{\mathrm{c}, \mathrm{d}}$, Pablo Ramil-Rego ${ }^{\mathrm{e}}$, Andrés Teira-Brión ${ }^{\mathrm{f}}$, Inés López-Dóriga ${ }^{\mathrm{g}}$, \\ António Lima ${ }^{\mathrm{h}}$, Rubim Almeida ${ }^{\mathrm{a}, \mathrm{b}, \mathrm{i}}$ \\ a CIBIO, Research Center In Biodiversity and Genetic Resources/University of Porto, Campus Agrário de Vairão, Universidade do Porto, 4485-601 Vairão, Portugal \\ b InBIO, Research Network in Biodiversity and Evolutionary Biology (Associated Laboratory), Campus Agrário de Vairão, Universidade do Porto, $4485-601$ Vairão, Portugal \\ c Department of History, Institute of Social Sciences, University of Minho, Campus de Gualtar, 4710-057 Braga, Portugal \\ d LAB2PT - Landscapes, Heritage and Territory, University of Minho, Portugal \\ e IBADER - Instituto de Biodiversidade Agraria e Desenvolvemento Rural, GI-1934, Territorio-Biodiversidade, Universidade de Santiago, (Campus de Lugo), Lugo, Spain \\ ${ }^{\mathrm{f}}$ Grupo de Estudos para a Prehistoria do NW Ibérico, Departamento de Historia I, Universidade de Santiago de Compostela, Praza da Universidade 1, 15782 Santiago de Compostela, Spain \\ g Wessex Archaeology, Portway House, Old Sarum Park, Salisbury SP4 6EB, UK \\ ${ }^{\text {h }}$ Estação Arqueológica do Freixo, Direção Regional de Cultura do Norte, Rua António Correia de Vasconcelos, 51 - Freixo, 4630-095, Freixo, Portugal \\ i Dept. of Biology, Fac. of Science, Univ. Porto and Herbarium and Museum of Natural History and Science (PO), R. do Campo Alegre, Ed. FC4, s/n, 4169-007 Porto, Portugal
}

\section{A R T I C L E I N F O}

\section{Article history:}

Received 30 May 2016

Accepted 7 July 2016

Available online xxxx

\section{Keywords:}

Archaeobotany

Seeds and fruits

Agriculture

Bronze age

NW Iberia

\begin{abstract}
A B S T R A C T
The wide and diverse array of palaeoenvironmental studies that were carried out in Northwestern Iberia indicate that the Bronze Age corresponds to a phase of great landscape changes. Strong deforestation and erosion episodes are key-features and they are usually assumed to be anthropogenic. The archaeological and archaeobotanical records demonstrate that these trends are coincident with modifications on settlement pattern and agricultural systems.

This work consists on a thorough revision of carpological data from 19 Bronze Age sites in order to understand agricultural practices in the region in this time period. Results reveal the increasing relevance of Panicum miliaceum and decreasing presence of naked barley which contrast with the previous periods. Carpological remains are not available in Early Bronze Age sites. Middle Bronze Age crops include naked and hulled forms of barley (Hordeum spp.) and wheat (Triticum spp.). Only one site provided occasional grains of Panicum miliaceum. Non-cereal crops are rare and comprise Linum, Papaver, Pisum sativum and Vicia faba. Still, there are few Middle Bronze Age sites with crop macroremains. Late Bronze Age sites with carpological remains of crops are more abundant but no new crop is added. This is the phase when Panicum miliaceum became a conspicuous crop in regional agricultural strategies. Overall, a small diversity of pulses is recorded throughout the Bronze Age, contrasting with other Iberian regions. Acorns (Quercus) are the only wild fruits consistently present in the archaeological sites and they probably had some relevance within the regional subsistence.

It was possible to detect changes on settlement and agricultural levels and suggest how these are related to environmental and social changes. It is argued that agricultural productivity increased and pits were the main storage facilities used by Bronze Age communities. Although these structures are abundant in several sites, caution is needed while interpreting them and their fills. Only in one site - Freixo - remains of crops were found in primary deposition in a storage pit.

Increasing agricultural productivity, including functionally diverse winter and spring crops seems to have been connected to settlement diversification. This trend may have led to a more complementary and profuse use of local resources, enhancing the anthropogenic changes in the landscape mentioned above. This was a further step in the territorialisation process that would eventually lead to the complex scenario recorded in the Iron Age.
\end{abstract}

(c) 2016 Elsevier Ltd. All rights reserved.

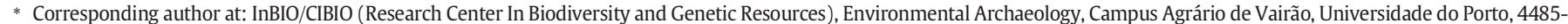
601 Vairão, Portugal.

E-mail addresses: jptereso@gmail.com (J.P. Tereso), anabett@uaum.uminho.pt (A.M.S. Bettencourt), ramil.rego@gmail.com (P. Ramil-Rego), andresteirabrion@gmail.com (A. Teira-Brión), i.lopezdoriga@wessexarch.co.uk (I. López-Dóriga), amlima@culturanorte.pt (A. Lima), rubim.almeida@fc.up.pt (R. Almeida).
} 


\section{Contents}

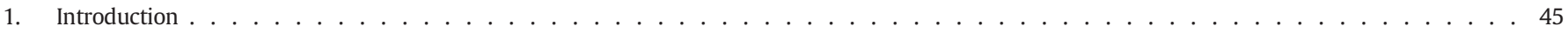

2. Geographical framework . . . . . . . . . . . . . . . . . . . . . . . . . . . . . . . . . 45

3. Materials and methods . . . . . . . . . . . . . . . . . . . . . . . . . . . . . . . . . . . 46

3.1. Sites with crop macroremains . . . . . . . . . . . . . . . . . . . . . . . . . . . . . . . . 47

3.1.1. Middle Bronze Age. . . . . . . . . . . . . . . . . . . . . . . . . . . . . . . . 47

3.1.2. Late Bronze Age . . . . . . . . . . . . . . . . . . . . . . . . . . . . . . . . . . . 48

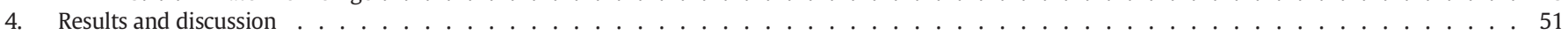

4.1. Bronze Age crops according to carpological data . . . . . . . . . . . . . . . . . . . . . . . . 51

4.2. Agriculture and settlement pattern in the Bronze Age . . . . . . . . . . . . . . . . . . . . . . . . . . . . . 54

5. Conclusions: crops, societies and environment from the end of the 3rd to the mid-1st millennia BC. . . . . . . . . . . . . . . . . . . . . . . . 55

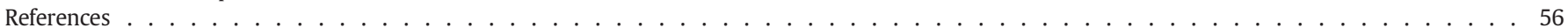

\section{Introduction}

Abundant palaeoenvironmental studies have been carried out in Northwestern Iberia, ranging from traditional approaches such as palynological studies done in wetlands that combine palynological data with sedimentary and geochemical approaches (e.g. van Mourik, 1986; Ramil Rego, 1992, 1993b; Ramil Rego et al., 1998; Muñoz Sobrino et al., 2001, 2004, 2007; Mighall et al., 2006) and archaeological sites (e.g. Aira Rodríguez and Ramil-Rego, 1995; López Sáez and Cruz, 2002; López Sáez et al., 2000, 2010; López-Merino et al., 2011), or even other disciplines such as pedoanthracology (Carrión et al., 2010; Kaal et al., 2011). Anthracological studies done in archaeological sites are also abundant (e.g. Figueiral, 1990; Figueiral and Bettencourt, 2004; Martín Seijo et al., 2011; Martín Seijo, 2013, Martín-Seijo et al., 2015). Such profuse and diversified set of studies has led to several syntheses on the palaeoenvironmental evolution of the region, namely regarding trends in landscape and climate (Fábregas Valcarce et al., 2003; Muñoz Sobrino et al., 2005; Martínez-Cortizas et al., 2009; Ramil Rego et al., 2009; Kaal et al., 2011; López-Merino et al., 2012).

These studies demonstrate that unprecedented deforestation, most likely anthropogenic, took place during the Bronze Age, mostly from 2000 to 1500 cal BC onwards (i.e. in Early and Middle Bronze Ages), marking the palaeoenvironmental history of Northwestern Iberia. Many sequences from Northern Portugal and Galicia, in Northwestern Spain (van Mourik, 1986; Ramil Rego, 1992; Muñoz Sobrino et al., 1997; Muñoz Sobrino, 2001; López-Merino et al., 2012) as well as in other Northern Iberian mountain areas (Muñoz Sobrino et al., 1997; Muñoz Sobrino, 2001) show a great reduction in arboreal pollen during this period. Similar spectra were identified in archaeopalynological (Aira Rodríguez and Ramil-Rego, 1995) and anthracological (Figueiral, 1990, 1993; Figueiral and Bettencourt, 2004, 2007) studies. This high deforestation, coincident with an increase in soil erosion and acidification and indications of heavy-metal atmospheric pollution, point to a probable anthropogenic cause (Martínez-Cortizas et al., 2009). A slightly colder climate could have contributed further to the decrease in arboreal vegetation (Fábregas Valcarce et al., 2003; Ramil Rego et al., 2009; Martínez-Cortizas et al., 2009; López-Merino et al., 2010; Kaal et al., 2011; Lillios et al., 2016). Therefore, the Bronze Age occurs, in large part, during a possibly colder period, except, the Late Bronze Age when some climatic amelioration took place (Ramil Rego et al., 2009).

Nevertheless, regional differences have been identified in the landscape evolution of Northwest Iberia. These have been studied in detail by Muñoz Sobrino (2001), after the early works of Van Mourik (1986) and P. Ramil Rego (1992, 1993b). More recent works complemented these models (e.g. Muñoz Sobrino et al., 2004, 2007; Kaal et al., 2011; López-Merino et al., 2012). According to the available data, deforestation in coastal, sub-coastal and low to mid altitude areas seems to have been fast and intense. On the other hand, in high altitude areas in the mainland, deforestation occurred later and was less intense probably due to unfavorable conditions for agricultural activities.
Considering that such landscape changes are to a great extent the result of human actions, it is of the upmost importance to understand at which level there is archaeological data related to these. Here we review the carpological data from Northwestern Iberian Bronze Age sites to detect eventual trends on the agricultural level and relate them not only to palaeoenvironmental records but also to social and cultural processes.

Archaeological work in Bronze Age sites in Northwestern Iberia has been profuse. The Bronze Age is probably one of the periods, which provided wider and more diversified sets of data. In fact, although there are clear regional and chronological gaps in the investigation of the region, the available data has led to several regional syntheses (Jorge, 1988; Martins, 1990; Méndez Fernández, 1994; Jorge, 1995; Fábregas Valcarce and Bradley, 1995; Bettencourt, 1995; Jorge, 1996; Fábregas Valcarce, 1998; Bettencourt, 1999; Bettencourt, 2005b; Jorge and Jorge, 2006; Bettencourt, 2009, 2010a, 2010b, 2013a, 2013b; Sampaio, 2014; Vieira, 2014; Bettencourt and Sampaio, in press).

Despite being profuse, palaeoenvironmental and archaeological syntheses seldom include systematic analysis of the carpological data available for the region. There are some exceptions (e.g. Bettencourt, 1999; Bettencourt et al., 2007; Sanches et al., 2007) but these are mostly environmentally or archaeologically centered and do not explore in full detail carpological data. Those that really focus on archaeological seeds and fruits are already outdated (da Silva, 1988; Ramil Rego, 1993a; Dopazo Martínez et al., 1996; Ramil Rego et al., 1996a, 1996b, Oliveira, 2000).

Combined analyses of carpological and archaeological data are crucial in order to enhance our knowledge regarding the evolution of agricultural systems and their relation with social changes, thus being essential to fully understand broad environmental changes. Taking into consideration the limitations of previous studies, the current approach, gathering archaeological, archaeobotanical and other palaeoenvironmental data, is particularly relevant to achieve a proper understanding of major trends in past societies and agriculture in Northwestern Iberia.

\section{Geographical framework}

This review focuses on North-western Portugal (districts of Porto, Braga, Viana de Castelo and Vila Real) and North-western Spain (Galicia) (Fig. 1). It is a heterogeneous region with a coastal area fragmented by numerous fluvial valleys sometimes with ample estuaries. Subcoastal areas are characterized by a succession of fluvial valleys, small sedimentary basins and low altitude mountains (most of the highest peaks are between 800 and $1150 \mathrm{~m}$ ). In the mainland we find large sedimentary basins, delimited by high altitude mountains (Peneda, $1545 \mathrm{~m}$; A Cabeza de Manzaneda, 1778 m, Pena Trevinca, 2127 m Mustallar, $1935 \mathrm{~m}$.) that link this territory to the Cantabrian Mountains and the Iberian Meseta to the East.

Bioclimatically, most of the study-area is placed in temperate and temperate submediterranean macrobioclimatic areas. In Galicia, termotypes range mostly from Upper thermotemperate to Upper 


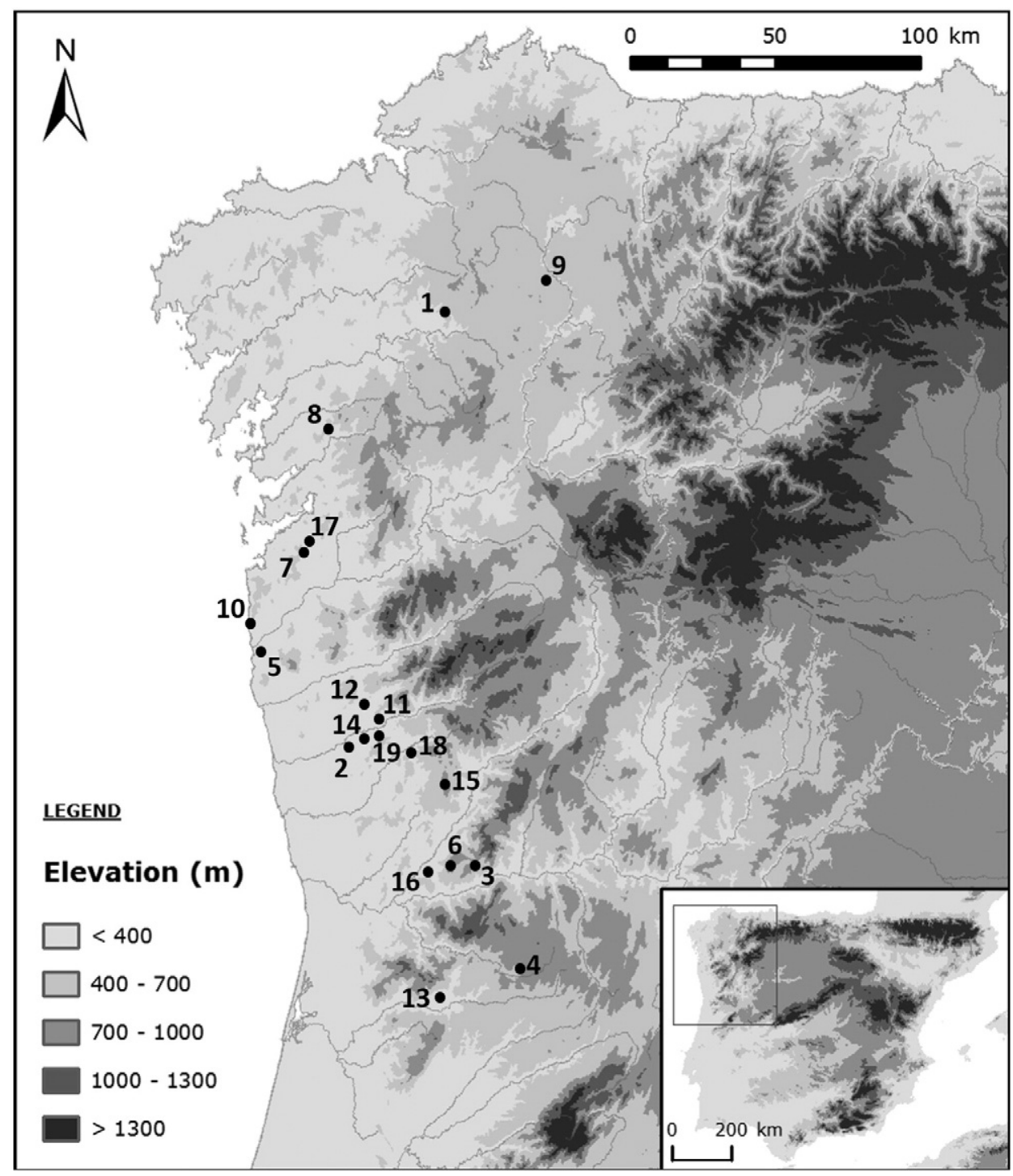

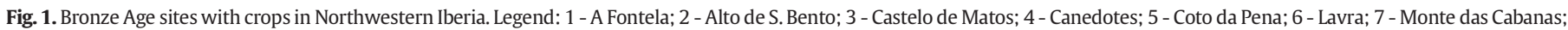

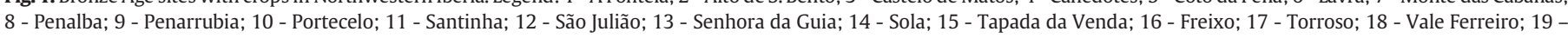
Vasconcelos.

supratemperate, with relevant areas of Lower mesotemperate and Upper mesotemperate (Rodríguez Guitián and Ramil-Rego, 2007). In Northwestern Portugal there is a predominance of Lower Upper thermotemperate and Mesomediterranean areas, with some Lower mesotemperate (Mesquita and Sousa, 2009).

Thus, most of the study-area is characterized by the absence of a dry season. Its proximity to the sea, together with its low altitudes, justifies its reduced continentality and the long vegetative period that may extent to 8-9 months. On the other hand, in the rest of the year, abundant frost or snow impose great limitations to the development of vegetation. The most suitable areas for agriculture are those from low altitude coastal and subcoastal areas.

\section{Materials and methods}

All reliable carpological data was gathered and synthesised in this study, covering a time span from c. $2300 / 2200$ cal BC to $600 / 500 \mathrm{cal}$ $\mathrm{BC}$, the proposed chronology for the Bronze Age of Northwestern Iberia, according to A.M.S. Bettencourt (1999, 2005a). According to other authors, the Iron Age begins at 800 cal BC in the region (González-Ruibal, 2003; Jordá Pardo et al., 2009). Sites with crops in a time-span between 600 and $400 \mathrm{cal} \mathrm{BC}$ considered as a period of transition between the
Bronze Age and the Iron Age (Bettencourt, 1999, 2005a) such as Penalba (Campolameiro, Spain), Penarrubia (Lugo, Spain), S. Julião Id (Vila Verde, Portugal) and Vasconcelos (Braga, Portugal) are also included. Data from Chalcolithic sites (e.g. Bettencourt et al., 2007; Tereso, 2012) were also mentioned for comparison.

Only sites with carbonized crops were included in this review. There are no Bronze Age sites with waterlogged fruits and seeds in the study area, nor mineralized remains. Uncharred plant remains are not considered here. The original contexts as well as the available information regarding the sampling strategies and recovery techniques are mentioned below.

In several Northwestern Iberian sites, some remains have been identified as seeds from Brassicaceae, namely Brassica/Sinapis (Ramil Rego et al., 1990; Ramil Rego, 1993a, Dopazo Martínez, 1996; Oliveira, 2000). Our revision of these materials and their comparison with modern material made us question these identifications. Thus, these remains were not included in this synthesis.

A further problem concerns with the nomenclature and identification criteria used by the different investigators who worked in the region. Published data is usually vague regarding the criteria used by the different investigators for the discrimination of the different crops. Therefore, there is a possibility that these were different and 
contradictory. This is particularly problematic in the case of wheat grains due to the well-known difficulties in distinguishing different species by their morphology (Hillman et al., 1996; Buxó, 1997; Jacomet, 2006).

Regarding the nomenclature, the only relevant issue concerns the short roundish grains of free-threshing wheat. The multiplicity of designations used by different investigators in the region forced us to homogenize designations in order to allow comparisons. The designation Triticum "stubby grains" was used. This was introduced by S. Jacomet (2006) and refers to grains which are shorter and more roundish than those typical of the T. aestivum/durum/turgidum type. Three species are usually ascribed to this morphology - T. aestivum subsp. compactum, T. aestivum subsp. sphaeorococcum and T. parvicoccum (Jacomet, 2006). Although underdeveloped grains (due to their position in the spike) of T. aestivum/durum/turgidum can present the same morphological features, different species could have existed. The need to use a generic morphological designation is due to the impossibility to distinguish between the different species.

The homogenization of the nomenclature, by using the designation Triticum "stubby grains", serves a purpose of allowing comparisons between sites studied by different investigators as the maintenance of different nomenclatures could create an idea of wheat diversity that is impossible to confirm.

\subsection{Sites with crop macroremains}

Crop macroremains were found in 19 Bronze Age sites. Unfortunately, these do not include any Early Bronze Age site. Here we present a synthesis regarding the sampling strategies and contexts (type of contexts and chronologies) where carpological remains were found. It is clear that the information concerning these two matters vary significantly among the different sites.

\subsubsection{Middle Bronze Age}

Alto de S. Bento (Braga, Portugal) - Open-air settlement located in a spur over the Cávado Valley. 15 pits of diverse morphologies and depths were excavated or partially excavated and all sediment was recovered. The pits had sub-circular and elongated mouth contours and had depths between $0.16 \mathrm{~m}$ and $1.04 \mathrm{~m}$ (Bettencourt, 1999, 2000a). Artifacts recovered in the site suggest an occupation from the 2nd millennium BC (Bettencourt, 2009). No radiocarbon date is available.

Only Pit 3 is yet studied. Its mouth measures $0.76 \mathrm{~m} \times 0.70 \mathrm{~m}$ and it is $1.04 \mathrm{~m}$ deep. From this structure, samples amounting to $24 \mathrm{l}$ of sediment were dry-sieved. There is no information regarding mesh size. Carpological remains were studied by M. Giselda Oliveira (2000).

Freixo (Marco de Canaveses, Portugal) - Open-air Late Bronze age site located at the Área Arqueológica de Freixo, at the base of the hillfort of Tongobriga, an Iron-Age and Roman settlement between the rivers Douro and Tâmega. Within the framework of the ongoing research project at this archaeological site (Lima, 2014), a series of radiocarbon dates have been obtained from charred plant macroremains recovered in 3 of the 23 pits identified and excavated in the course of recent archaeological fieldwork near the Roman baths and Forum of Tongobriga (LópezDóriga, 2015). The modeled radiocarbon dates, concentrated between the 1600 and $1250 \mathrm{cal} \mathrm{BC}$, point to the occupation of the site between 1500 and 1450 cal BC (Table 1 ).

All the excavated sediment has been floated with a Syraf-type machine and the floating fraction has been retrieved with a piece of cloth of $0.25 \mathrm{~mm}$ mesh size. A sample of each pit has been assessed and all the samples from one of the pits (Pit 15) have been analyzed.

The area in which the pits were dug had been previously worked by flattening the decomposed granite. The nature of these earthworks has been distorted by the extensive transformation of the area undertook for the construction of the Roman Forum. Modern farming activity has also been carried out in the area, producing plough marks on the surface of the decomposed granite. The pits may be ascribed to several morphological types, have a single fill or are multilayered, and contain variable densities of pottery fragments and charred plant macroremains of wild and domestic species. Pit 15, the only one yet studied in full, is $0.85 \mathrm{~m}$ depth, has first divergent and then convergent walls, concave bottom and has provided evidence of its primary use as a storage pit, in the form of a crust of charred grain (a high proportion of it being sprouted) adhering to the lower part of the walls and the bottom. Two opposing indentures at the upper part of the walls just below the mouth have been tentatively identified as potential receptacles for a lid.

Carpological remains were studied by Inés López-Dóriga and were previously unpublished.

Monte das Cabanas (Vigo, Galicia/Spain) - Open-air settlement located in a flat area of a mountainside. Several pits were excavated; some were identified as storage structures and other are of undetermined functionality (Rodríguez Saiz, 2010). Pits are $0.45 \mathrm{~m}$ to $1.90 \mathrm{~m}$ deep and show variable widths in the mouths. These tend to form a funnel (Rodríguez Saiz, 2010). Features of recovered materials show that storage-pits had played a role in social practices after their use as storage structures. The settlement was occupied during the Middle Bronze Age, between the 19th and the 13th centuries cal BC. A Maloideae charred fruit from the lower level of a storage-pit was dated to 1880 1689 cal BC (Table 1$)$.

The remains were hand-picked during the excavation process. Sediment has not been floated. Carpological remains are unpublished and were studied by Andrés Teira Brión.

Portecelo (O Rosal, Galicia/Spain) - Open-air settlement in a spur overlooking the coastal platform, with only one occupation level. A hearth floor with a stone pavement was found in the vicinity.

Table 1

Radiocarbon dates of Middle Bronze Age archaeological sites. 14C dates calibrated using Oxcal 4.2 (curve IntCal 13) (Reimer et al., 2013).

\begin{tabular}{|c|c|c|c|c|c|c|}
\hline Site & Lab. ref. & Contexts & Date BP & 1 sigma cal. BC & 2 sigma cal. BC & References \\
\hline $\begin{array}{r}\text { Monte das } \\
\text { Cabanas }\end{array}$ & Beta-393992 & $\begin{array}{l}\text { Pit } 1 \text { (SU017) Maloideae } \\
\text { fruit }\end{array}$ & $3450 \pm 30$ & $\begin{array}{l}1870-1845(15.2 \%) \\
1811-1804(3.6 \%) \\
1776-1733(31.8 \%) \\
1718-1694(17.5 \%)\end{array}$ & $1880-1688(95.4 \%)$ & Unpublished \\
\hline Sola IIb & $\begin{array}{l}\text { Weighted average } \\
4 \text { dates }\end{array}$ & Cuts 1 and 2 & $3334 \pm 20$ & $\begin{array}{l}1684-1608(57.2 \%) \\
1581-1562(11.0 \%)\end{array}$ & $\begin{array}{l}1685-1600(73.70 \%) \\
1586-1534(21.7 \%)\end{array}$ & Bettencourt (2000b: 47) \\
\hline Freixo & Span 4 dates & $\begin{array}{l}\text { Pits, } 15,20 \text { and } 22 . \\
\text { Cereal grains. }\end{array}$ & $\begin{array}{l}3240 \pm 28 \\
3210 \pm 30 \\
3083 \pm 31 \\
3210 \pm 30\end{array}$ & $1495-1443(68.2 \%)$ & $1501-1427$ (95.4\%) & Unpublished \\
\hline Tapada da Venda & Ua-19499 & Cut 1 & $3065 \pm 50$ & $1398-1268(68.2 \%)$ & $\begin{array}{l}1436-119(94.8 \%) \\
1141-1134(0.6 \%)\end{array}$ & Bettencourt et al. (2002) \\
\hline Tapada da Venda & CSIC-1830 & Cut 2 & $3057 \pm 30$ & $\begin{array}{l}1388-1338(35.1 \%) \\
1319-1271(33.1 \%)\end{array}$ & $\begin{array}{l}1408-1256(90.3 \%) \\
11,251-1231(5.1 \%)\end{array}$ & Bettencourt et al. (2007) \\
\hline Portocelo & CSIC-744 & Archaeological level & $3050 \pm 50$ & $\begin{array}{l}1394-1334(29.2 \%) \\
1326-1258(33.3 \%) \\
1247-1232(5.8 \%)\end{array}$ & $\begin{array}{l}1427-1192(92.7 \%) \\
1176-1163(1.2 \%) \\
1144-1131(1.5 \%)\end{array}$ & Fábregas Valcarce and Ruíz-Gálvez Priego (1997) \\
\hline
\end{tabular}


Cano Pan and Vázquez Varela $(1988,1991)$ mention the presence of plant remains (acorns and cereals). The authors do not provide any information regarding sampling strategy and recovering methods. In early works a Late Bronze Age chronology was proposed. However, the calibration of the radiocarbon date obtained in the $1980 \mathrm{~s}$ (Table 1) and analysis of the ceramic material, in parallel with the Sola settlement, led Bettencourt (1999) to integrate it in the Middle Bronze Age.

Sola IIb/Bouça do Ouro (Braga, Portugal) - Open-air settlement in a spur of a residual hill on the Cávado Valley. Crop macroremains were retrieved in two areas (Cuts 1 and 2). In Cut 1, the crops were retrieved from four pits: numbers 1, 2, 3/4 and 5. Acorns were found only in pits 1 and 2 (Bettencourt, 2000b). The totality of the pits sediments and a sample of 51 per layer/square were sieved with a $1 \mathrm{~mm}$ mesh.

- In Cut 1, layer 3, post-holes from an elliptical structure (hut) and eight pits were excavated. Pits 2, 3/4 and 5 had different shapes, with mouths between $0.64 \mathrm{~m}$ and $0.96 \mathrm{~m}$ and depths between $0.50 \mathrm{~m}$ and $0.75 \mathrm{~m}$. Pits 7, 8 and 9 did not provide plant remains and were interpreted as possible furnaces. Two radiocarbon dates, obtained from wood charcoal of a possible hearth, placed this occupation in the 17th century cal BC, i.e. the Middle Bronze Age (Table 1) (Bettencourt, 2000b).

- In Cut 2, layer 2, a hut-floor and post-holes were found in an area with some little stone structures interpreted as cists. Carpological remains were almost absent. Only remains of two crops were detected, associated with the hut-floor. Two radiocarbon dates were obtained from charcoals recovered inside one of the possible cists, suggesting a chronology within the 17th and 16th centuries cal BC (Table 1) (Bettencourt, 2000b).

Carpological remains were studied by Ramil Rego, 1993b, Aira Rodríguez and Ramil-Rego (1995); and Maria Giselda Oliveira (2000).

Tapada da Venda (Celorico de Basto, Portugal) - Settlement located on a mid-altitude plateau. The site was occupied in the second half of the 2nd millennium cal BC (i.e. the end of the Middle Bronze Age) (Bettencourt et al., 2002, 2007). The chronology was confirmed by radiocarbon dates (Table 1) (Bettencourt et al., 2002; Bettencourt et al., 2007).

Layer 1 in Cut 2, was the only that provided carpological remains. These were associated to 8 pits, a very irregular stone floor, a clay floor and 20 post-holes. The pits had various shapes (mouths ranging from c. $1.10 \mathrm{~m}$ to c. $0.30 \mathrm{~m}$ long) and were shallow (depths rarely exceeded $0.30 \mathrm{~m})$.

All sediments from post-holes and pits were sieved with a $1 \mathrm{~mm}$ mesh. The same happened to the sediments that were immediately above the floors.

The carpological remains were studied by Isabel Figueiral but only qualitative data was published (Bettencourt et al., 2007). Here we present the absolute frequency of the remains.

\subsubsection{Late Bronze Age}

A Fontela (Palas de Rei, Galicia/Spain) - Open-air settlement characterized by negative structures of several types and chronologies, from the Chalcolithic to historical times. The A Fontela area consists of a $4 \mathrm{~m}$ wide and $2.25 \mathrm{~m}$ maximum depth annular ditch and some adjoining pits, all dated between the 10th and the 9 th centuries cal BC. The analyzed sample was recovered in a circular pit of $>1 \mathrm{~m}$ diameter and $0.30 \mathrm{~m}$ depth. A radiocarbon date obtained from a charred grain of Triticum dicoccum (Table 2) points to a Late Bronze Age chronology: 1050-895 cal BC.

The remains were recovered by flotation of a sample of 81 of sediment using meshes of $2 \mathrm{~mm}, 1 \mathrm{~mm}$ and $0.5 \mathrm{~mm}$. The site is still being studied. Carpological remains were identified by Andrés Teira Brión.

Canedotes (Vila Nova de Paiva, Portugal) - Open-air settlement located in the higher platforms of a conical mount, with profusion of granite outcrops, overlooking small valleys of the Paiva basin. Two sectors were excavated (Sectors I and II), in which small walls and stone floors were discovered (Canha, 2002). The occupation of this place took place in the Late Bronze Age, between the 10th and the 9th centuries cal $\mathrm{BC}$, according to radiocarbon dates (Table 2 ).

Plant remains were picked by hand during the excavation or from samples of sediment collected selectively. In the last case they were recovered with $3 \mathrm{~mm}$ mesh sieves (Canha, 2002: 37).

Carpological remains were studied by Isabel Figueiral and are still unpublished. The only information available points out the existence of acorns and wheat (Canha, 2002: 129).

Castelo de Matos (Baião, Portugal) - Open-air settlement or ceremonial place with a Late Bronze Age occupation ranging from the 10th to the 8th centuries cal BC (Table 2). One of the radiocarbon dates was obtained over a grape pip (Queiroga, 1992). The site provided a circular gray floor and a wood palisade (Queiroga and Figueiral, 1989; Queiroga, 1992).

Soil samples were collected and floated (personal information of F. Queiroga). The number and volume of samples that provided carpological remains, as well as their contexts are not known. The carpological remains were studied by Pinto da Silva (mentioned in Queiroga, 1992).

Coto da Pena (Caminha, Portugal) - Iron Age hillfort with a previous Late Bronze Age occupation, located in a spur overlooking the mouth of the river Coura, in the Minho estuary. In the Late Bronze Age level, an oval stone house with a gray floor was found. This floor provided a shell-midden with animal bone and mollusks and a large core of seeds, some of them Vicia faba. A portion of these seeds was used for a radiocarbon date (UGRA 200). At the same platform, a comparable Late Bronze Age level was found under the Iron Age house no. I, with a great quantity of seeds. Some of these seeds were used to obtain another radiocarbon date (UGRA 220) (Silva, 1986: 34-35, note 187) (Table 2).

Carpological remains were studied by Pinto da Silva (da Silva, 1988) but there is no information available regarding sampling strategy and recovery techniques.

Lavra (Marco de Canaveses, Portugal) - Open-air settlement with pits, post-holes, hearths and a hut-floor from the Late Bronze Age (9th century), confirmed by radiocarbon dates (Sanches, 1988, 1995; Cruz, 1997). The Late Bronze Age phase is known as Lavra II. The pits had sub-circular and ovoidal mouth contours (the mouth diameters ranging from $0.70 \mathrm{~m}$ to $1.00 \mathrm{~m}$ ) and depths between $0.70 \mathrm{~m}$ and $1.30 \mathrm{~m}$ ) (Sanches, 1988). The sediments from all the pits were recovered, together with some samples of sediment from the hearths' area (Sanches, 1988, 1995). There is no detailed information regarding the provenance of the carpological remains. Some cereals and Vicia faba were connected to hearth 5 (personal information of M. J. Sanches). They were studied by A.R. Pinto da Silva but raw data remains unpublished.

Penalba (Campo Lameiro, Galicia/Spain) - Settlement located in a hill overlooking the Lérez Valley, with a likely chronology within the 7th and the 6th centuries cal BC. The chronology is confirmed by several radiocarbon dates of the occupation level (Aira Rodríguez et al., 1990). During the excavation, soil samples of unknown volume were recovered in an area with three or four clay hut-floors, one hut-floor surrounded by a stonewall and some hearths. A fire in this area allowed the conservation of the carbonized seeds. Some of the cereal grains were embedded in fragments from ceramic containers (Álvarez Nuñez, 1986), probably indicating that these were storage vessels.

Carpological studies were carried out and published by different investigators (Téllez et al., 1990; Aira Rodríguez et al., 1990; Dopazo Martínez, 1996; Dopazo Martínez et al., 1996). Early studies by Téllez et al. (1990) were not taken into account here as they were carried out over a very small amount of grains and consisted solely on a biometric analysis by which the authors claim to have identified three different species of naked wheat. Such biometric approach has been criticized 
Table 2

Radiocarbon dates of Late Bronze Age archaeological sites. 14C dates calibrated using Oxcal 4.2 (curve IntCal 13) (Reimer et al., 2013).

\begin{tabular}{|c|c|c|c|c|c|c|}
\hline Archaeological sites & Lab. ref. & Contexts & Date BP & 1 sigma cal. BC & 2 sigma cal. BC & References \\
\hline Coto da Pena (VIL) & UGRA 200 & Layer 5 & $2930 \pm 100$ & $1274-998(68.2 \%)$ & 1408-902 (95.4\%) & Silva (1986) \\
\hline Coto da Pena (VIL) & UGRA 220 & Layer 9 & $2920 \pm 110$ & $\begin{array}{l}1264-976(67.6 \%) \\
950-946(0.6 \%)\end{array}$ & $\begin{array}{l}1408-893(93.9 \%) \\
874-850(1.5 \%)\end{array}$ & Silva (1986) \\
\hline São Julião Ia & $\begin{array}{l}\text { Weighted average } \\
11 \text { dates }\end{array}$ & Cuts $1,2,3 a, 3 b, 7$ & $2901 \pm 14$ & $1113-1054(68.2 \%)$ & $1126-1016(95.4 \%)$ & Bettencourt (2000d) \\
\hline Vale Ferreiro & AA 63068 & Pit 9 - house-tomb & $2875 \pm 41$ & $1120-996(68.2 \%)$ & $\begin{array}{l}1194-1142(8.4 \%) \\
1132-928(87 \%)\end{array}$ & Bettencourt et al. (2007) \\
\hline Santinha I & $\begin{array}{l}\text { Weighted average } \\
4 \text { dates }\end{array}$ & Cuts $1,2,3$ & $2810 \pm 19$ & $995-928(68.2 \%)$ & $1010-910(95.4 \%)$ & Bettencourt (2001) \\
\hline A Fontela & Beta-425860 & Pit SG 10 (SU112) grain T. dicoccum & $2810 \pm 30$ & $1000-924(68.2 \%)$ & $1050-895(95.4 \%)$ & Unpublished \\
\hline Castelo de Matos & OxA 2146 & Bronze Age level Vitis vinifera sp. & $2700 \pm 90$ & $\begin{array}{l}972-958(4.0 \%) \\
938-796(64.2 \%)\end{array}$ & $\begin{array}{l}1116-748(91.8 \%) \\
684-666(0.8 \%) \\
640-588(2.1 \%) \\
580-559(0.7 \%)\end{array}$ & Queiroga and Figueiral (1989) \\
\hline Castelo de Matos & OxA 2147 & Bronze Age level Vitis vinifera sp. & $2710 \pm 90$ & $\begin{array}{l}974-956(5.2 \%) \\
942-798(63.0 \%)\end{array}$ & $\begin{array}{l}1125-750(93.5 \%) \\
684-668(0.6 \%) \\
638-590(1.4 \%)\end{array}$ & Queiroga and Figueiral (1989) \\
\hline Castelo de Matos & OxA 1759 & Bronze Age level & $2730 \pm 70$ & $\begin{array}{l}968-964(1.4 \%) \\
931-810(66.8 \%)\end{array}$ & $1044-794(95.4 \%)$ & Queiroga and Figueiral (1989) \\
\hline Canedotes & $\begin{array}{l}\text { Weighted average } \\
5 \text { dates }\end{array}$ & $\begin{array}{l}\text { Sector I - wood charcoal } \\
\text { fragments and acorns }\end{array}$ & $2719 \pm 38$ & $900-827(68.2 \%)$ & $\begin{array}{l}968-964(0.5 \%) \\
931-805(94.9 \%)\end{array}$ & Canha (2002) \\
\hline Canedotes & GrN 25827 & Sector II - cereal grains & $2745 \pm 45$ & $926-831(68.2 \%)$ & $996-812(95.4 \%)$ & Canha (2002) \\
\hline Senhora da Guia & GrN-7484 & Wood fragment inside a spearhead & $2650 \pm 130$ & $\begin{array}{l}978-744(51.4 \%) \\
686-665(3.2 \%) \\
644-551(13.5 \%)\end{array}$ & $1110-412(95.4 \%)$ & Kalb (1974-1977) \\
\hline São Julião Ib & $\begin{array}{l}\text { Weighted average } \\
3 \text { dates }\end{array}$ & Cut 3a & $2781 \pm 30$ & $\begin{array}{l}993-987(2.7 \%) \\
980-896(65.5 \%)\end{array}$ & $1004-844(95.4 \%)$ & Bettencourt (2000d) \\
\hline São Julião Ic & $\begin{array}{l}\text { Weighted average } \\
3 \text { dates }\end{array}$ & Cut 3a & $2544 \pm 18$ & $794-762(68.2 \%)$ & $\begin{array}{l}797-750(74.7 \%) \\
684-667(7.9 \%) \\
637-590(12.0 \%) \\
576-570(0.8 \%)\end{array}$ & Bettencourt (2000d) \\
\hline Lavra II & $\begin{array}{l}\text { Weighted average } \\
2 \text { dates }\end{array}$ & - & $2671 \pm 39$ & $\begin{array}{l}891-879(8.7 \%) \\
845-800(59.5 \%)\end{array}$ & $902-796(95.4 \%)$ & Cruz (1997) \\
\hline Torroso & GrN 14589 & Level V - acorn & $2635 \pm 30$ & $818-796(68.2 \%)$ & $\begin{array}{l}842-780(95.1 \%) \\
887-884(0.3 \%)\end{array}$ & Peña Santos (1992) \\
\hline Torroso & GrN 14588 & Level IV - acorn & $2580 \pm 30$ & $802-773(68.2 \%)$ & $\begin{array}{l}814-750(87 \%) \\
684-668(3.1 \%) \\
637-622(1.4 \%) \\
616-590(3.9 \%)\end{array}$ & Peña Santos (1992) \\
\hline Torroso & GrN 13706 & Level II - acorn & $2555 \pm 30$ & $\begin{array}{l}799-755(57.6 \%) \\
680-670(5.4 \%) \\
606-596(5.2 \%)\end{array}$ & $\begin{array}{l}804-745(60.6 \%) \\
686-666(8.7 \%) \\
644-552(26.1 \%)\end{array}$ & Peña Santos (1992) \\
\hline Torroso & GrN 13705 & Level I - acorn & $2540 \pm 30$ & $\begin{array}{l}794-750(40.3 \%) \\
683-668(9.5 \%) \\
636-625(5.1 \%) \\
614-591(13.3 \%)\end{array}$ & $\begin{array}{l}799-736(44.4 \%) \\
688-662(12.2 \%) \\
647-547(38.9 \%)\end{array}$ & Peña Santos (1992) \\
\hline $\begin{array}{l}\text { Vasconcelos/Monte } \\
\text { do Crasto }\end{array}$ & UTC 4328 & Cut 1 & $2504 \pm 36$ & $\begin{array}{l}770-740(13.4 \%) \\
688-664(10.8 \%) \\
646-550(44.0 \%)\end{array}$ & $792-516(95.4 \%)$ & Bettencourt (2000a) \\
\hline Penarrubia & CSIC 358 & Sector C (layer 3) & $2510 \pm 50$ & $\begin{array}{l}784-732(18.2 \%) \\
690-661(10.8 \%) \\
649-545(39.2 \%)\end{array}$ & $\begin{array}{l}798-478(94.3 \%) \\
444-432(1.1 \%)\end{array}$ & Arias Vilas (1979) \\
\hline Penalba & GrN-14132 & $\begin{array}{l}\text { Floor (square C4) wood } \\
\text { charcoal fragments }\end{array}$ & $2485 \pm 35$ & $\begin{array}{l}762-729(12.3 \%) \\
692-658(12.6 \%) \\
652-542(43.2 \%)\end{array}$ & $\begin{array}{l}782-480(94.5 \%) \\
442-432(0.9 \%)\end{array}$ & Aira Rodríguez et al. (1990) \\
\hline Penalba & GrN-14133 & Fire place (square C3) acorns & $2445 \pm 30$ & $\begin{array}{l}736-688(20.1 \%) \\
663-647(6.2 \%) \\
548-430(41.8 \%)\end{array}$ & $\begin{array}{l}752-682(25.1 \%) \\
670-612(13.3 \%) \\
593-410(57.0 \%)\end{array}$ & Aira Rodríguez et al. (1990) \\
\hline Penalba & GrN-14134 & $\begin{array}{l}\text { Floor (square C4) wood } \\
\text { charcoal fragments }\end{array}$ & $2490 \pm 35$ & $\begin{array}{l}765-731(13.1 \%) \\
690-660(11.8 \%) \\
650-544(43.3 \%)\end{array}$ & $788-486(95.4 \%)$ & Aira Rodríguez et al. (1990) \\
\hline Penalba & Ref. 234 & $\begin{array}{l}\text { Fire place on a floor (square B4) } \\
\text { wood charcoal fragments }\end{array}$ & $2584 \pm 126$ & $\begin{array}{l}892-876(2.5 \%) \\
848-536(65.7 \%)\end{array}$ & $996-402(95.4 \%)$ & Aira Rodríguez et al. (1990) \\
\hline
\end{tabular}

(Dopazo Martínez, 1996). Aira Rodríguez et al. (1990) did a partial study of 7 samples. Dopazo Martínez (1996) completed the study of the same samples. A $1 \mathrm{~mm}$ mesh was used.

Penarrubia (Lugo, Galicia/Spain) - Settlement located in a circular hill overlooking the Minho Valley with only one occupation level. Two areas were excavated: the area $\mathrm{C}$ on the top and the area $\mathrm{M}$ on the west slope. Both of them were characterized by the traces of a fire (charcoal, ashes and blackened soils) and the presence of remains (great number of coating clay with negative of straws, branches and wood) from perishable huts (Arias Vilas, 1979). At the West slope there was a rudimentary wall. In the excavated area, three complete hand mills and fifty-eight other fragments were found. This settlement was occupied from the 8th to the beginning of the 5th century cal BC, according to a radiocarbon date (Table 2 ). 
Archaeobotanical publications make no reference to contexts and recovery techniques (Dopazo Martínez, 1996; Dopazo Martínez et al., 1996; Ramil Rego et al., 1996a, 1996b).

São Julião (Vila Verde, Portugal) - Settlement/ceremonial site located on a spur of the Serra Amarela, overlooking the Homem Valley. Two Late Bronze Age occupations (São Julião Ia and Ib/Ic) and one of the Late Bronze Age/Iron Age transition (São Julião Id) were distinguished (Bettencourt, 1999, 2000d, 2013a, 2013b). All phases are dated by radiocarbon.

São Julião la dates from the late 12 th century to the late 11 th century cal BC and corresponds to the oldest moment of occupation in the top of the little hill located in the spur. In this phase, the site was an open-air settlement with some hut-floors of clay surrounded by small stones and post-holes, hearths and a pit (Bettencourt, 1999, 2000d).

São Julião Ib/Ic corresponds to a long occupation that began somewhere between the beginning of the 10th century cal BC and the middle of the 9th century cal BC and finished in the 8th century cal BC. In the beginning of this period the site was an open-air settlement. During the 9th century São Julião was monumentalized by the construction of two rudimentary walls and a partial trench at the entrance of the top area. Some clay or stone huts-floors and fires were found inside the walls.

São Julião Id dates from the 8th century cal BC to the beginning of the 4th century cal BC. It corresponds to the phase of the settlement enlargement, only detected in the platforms of the slopes of the hill. It is a phase in which the structures are still built in perishable materials, materialized by huts with clay floors and fireplaces; one embankment and enclosed structures by stones or little piles of stone of small diameters, probably funerary (Bettencourt, 1999, 2000d).

Plant macroremains were recovered either from samples of sediment sieved with a $1 \mathrm{~mm}$ mesh or handpicked during the excavations. Sieved sediments include all soil from the pit of São Julião Ia and several 51 samples recovered in hut floors of São Julião Ib and Ic. Their study was carried out by Aira Rodríguez and Ramil-Rego (1995); Dopazo Martínez, 1996) and M. Giselda Oliveira (2000). Dopazo Martínez (1996) documents 29 handpicked samples. The information regarding the contexts where each sample was recovered in her text relates to the sector, cut and square of the site (Dopazo Martínez, 1996). By Bettencourt $(1999,2000 d)$ it is possible to know the general context. All these samples were recovered from soils related with a hut-floor. M. Giselda Oliveira (2000) ascribes the remains to the four different phases as had been proposed by Bettencourt (1999), but due to their overlapping chronology and to facilitate data presentation, in this study three phases will be considered: São Julião la (Late Bronze Age), São Julião Ib/Ic (Late Bronze Age) and São Julião Id (Late Bronze Age/ Iron Age Transition).

Santinha (Amares, Portugal) - Open-air settlement located in a hill overlooking the Cávado Valley, characterized by the presence of pits and a retaining wall (Bettencourt, 1999, 2001). Crops were retrieved in three different areas (Cuts 1, 2 and 3). Soil sampling strategy implied the recovery of a 51 sample per layer/square and the full content of the pits (Bettencourt, 1999, 2001). The exception was Pit 1 of the layer 1, inside the Cut 1 (Bettencourt, 2001). Sediments were sieved with a $1 \mathrm{~mm}$ mesh (Bettencourt, 1999, 2001).

- Cut 1 is located in the upper platform of the site. Two different occupation levels were identified. In layer 1 , three pits were excavated but ancient earthworks on site destroyed their upper levels. These pits had circular mouth contours (mouth diameters ranging from $2.62 \mathrm{~m}$ to $2.5 \mathrm{~m}$ ) and shallow depths (between $0.46 \mathrm{~m}$ and $0.72 \mathrm{~m}$ ). In layer 2, five pits were excavated. They were, probably, located inside a hut built with perishable materials (post-holes) and a stone basement. These pits had circular and oval shapes (mouth ranging from $1.20 \mathrm{~m}$ to $0.60 \mathrm{~m}$ wide) and were shallow (depths between $0.26 \mathrm{~m}$ and $0.72 \mathrm{~m}$ ).

- Cut 2 is located at the beginning of the southern slope of the hill. Two occupation levels were identified. Each layer provided one pit with plant remains. Pit in layer 1 , with circular shape, had a mouth of $1.34 \mathrm{~m}$ wide and a depth of $1.02 \mathrm{~m}$. Pit in layer 2, with sub-circular shape, had a mouth $0.76 \mathrm{~m}$ wide and a depth of $0.40 \mathrm{~m}$. In this layer was discovered a semi-underground hut with c. $3 \mathrm{~m}$ in diameter and 0.70 m deep where most carpological remains were found (Bettencourt, 1999, 2001: 29-30).

- Cut 3 is also located at the southern slope of the hill. Layer 1 provided one pit, one hut-floor, a cist and a retaining wall. The pit was $1.2 \mathrm{~m}$ wide and $0.74 \mathrm{~m}$ deep. The plant remains were collected from the pit, the hut-floor and from a ceramic container.

Radiocarbon dates and the analysis of artifacts position layer 2 from Cut 1 and 2 and layer 1 from Cut 3 in the 10th century cal BC (Bettencourt, 1999, 2001; Rubinos Pérez, 2001) (Table 2). Layer 1 from Cuts 1 and 2 are also from the Late Bronze Age but of a more recent chronology, somewhere after the 10th century BC. The ceramic technology and typology of these layers, suggests this occupation is from the 9th century and 8/7th centuries BC (Bettencourt, 2001).

Carpological remains were studied by Dopazo Martínez (1996) and M. Giselda Oliveira (2000). Correspondence between samples and occupation phases was updated according to archaeological data (Bettencourt, 2001) and do not completely match previous studies.

Senhora da Guia (Baiões, São Pedro do Sul, Portugal) - Open-air settlement located in a conical hill overlooking the Vouga Valley. The excavations of the Sector B1 (at the high platform of the North slope), provided evidence of a single Bronze Age occupation level (Silva, 1979; Kalb, 1980). This level was characterized by the remains of huts, formed by fragile alignments of stones, arranged in circles, with hearth floors and fireplaces inside. In this sector, carpological remains were found in association to hand mills, ceramics and bronze artefacts, like sickles and axes (Silva et al., 1984; Silva, 1986: 35, note 191 and Fig. XIV). The presence of specific bronze artefacts and the forms of the ceramic vessels point to a Late Bronze Age chronology.

Carpological remains were studied by Pinto da Silva (da Silva 1976, 1988) but there is no information available regarding sampling strategy and recovery techniques.

Torroso (Mos, Galicia/Spain) - Settlement inhabited between the ends of the 9th century to the 7th century cal BC, as confirmed by radiocarbon dates (Table 2). Torroso is located in a mound, overlooking the Louro Valley (Peña Santos, 1992). According to Peña Santos (1992) Torroso has only an occupation phase, although it experienced different construction moments.

The first moment of Torroso (Levels V and VI) is characterized only by artifacts' debris. Just in Phases "IV, III, II and I" we find noticeable structures such as the basal part of a few stone huts and adobe walls, alongside other huts built in perishable materials and postholes. There were also fireplaces and pits. It were also in these moments that earth retaining walls, ditches and embankments were built (Peña Santos, 1992). Carpological remains appeared in every archaeological levels, although the concentrations of wheat and acorns were more significant in the last constructive moment (Peña Santos, 1992: 43). In the center of a circular hut floor, a fireplace was found with a cluster of charred acorns and grains of wheat (Peña Santos, 1992). The carpological data were studied by Ramil Rego (1993a) and Dopazo Martínez et al. (1996).

Vale Ferreiro (Fafe, Portugal) - Site interpreted as being related to the cult of the dead and the ancestors with few but different kinds of tombs (exceptional subterranean tombs built with stones; flat graves and pits) (Bettencourt, 2005a, 2005b; Bettencourt et al., 2005; Sampaio, 2014). The site was frequented between the Early Bronze Age and the Late Bronze Age, as testified by several radiocarbon dates covering the end of the 3rd to the end of 2nd millennia cal BC (Bettencourt, 2005a, 2005b; Sampaio, 2014).

It is located in a spur, surrounded by little valleys, near the Ave Valley (Bettencourt, 2005a, 2005b; Sampaio, 2014). All sediment from the pits was collected and floated, but only one provided archaeological carpological remains: the Pit 9, interpreted as a house-tomb belonging 
to the Late Bronze Age (Table 2) (Bettencourt, 2005a, 2005b; Bettencourt et al., 2007; Sampaio, 2014). These results are consistent with the interpretation of the place as funeral and ceremonial. Seeds were also recovered in Pit 11 (cf. Bettencourt et al., 2007: 157, Table 3) but this structure was interpreted as an animal burrow from a later period.

The carpological remains were studied by Isabel Figueiral but only qualitative data was published (Bettencourt et al., 2007). Here we present the absolute frequency of the remains.

Vasconcelos/Monte do Crasto (Braga, Portugal) - Settlement in a mount of Serra do Carvalho, overlooking the valley of the Gualtar stream, within the basin of river Este. Only two small test pits were opened (Cut 1 and 2). Soil erosion limited site preservation, thus only in Cut 1 , on the top of the hill, was identified the foundation of an irregular wall, some pottery sherds and lithic objects (Bettencourt, 2000a). Only one 51 soil sample was dry-sieved using a $1 \mathrm{~mm}$ mesh. This sample was recovered in Cut 1 (layer 1a of the B4 square), a severely eroded occupation level dated from the 7th century to the beginning of the 6th century cal BC, according to a radiocarbon date (Bettencourt, 1999) (Table 2).

The few carpological remains were studied by Dopazo Martínez et al. (1996).

Table 3

Carpological remains in Middle Bronze Age sites.

\begin{tabular}{|c|c|c|c|c|c|c|}
\hline & $\begin{array}{l}\text { Alto de } \\
\text { S. Bento }\end{array}$ & Freixo & $\begin{array}{l}\text { Monte das } \\
\text { Cabanas }\end{array}$ & Portecelo & Sola & $\begin{array}{l}\text { Tapada } \\
\text { da Venda }\end{array}$ \\
\hline \multicolumn{7}{|l|}{ Cereals } \\
\hline Hordeum sp. & & 40 & & a & & \\
\hline $\begin{array}{l}\text { Hordeum vulgare var. } \\
\text { nudum }\end{array}$ & & 272 & & & & \\
\hline $\begin{array}{l}\text { Hordeum vulgare } \\
\text { subsp. vulgare }\end{array}$ & & 2 & & & & 1 \\
\hline $\begin{array}{l}\text { Hordeum vulgare } \\
\text { (chaff) }\end{array}$ & & 234 & & & & \\
\hline Panicum miliaceum & & & & & 3 & \\
\hline Triticum aestivum/durum & & 401 & 1 & & & \\
\hline $\begin{array}{l}\text { Triticum aestivum/durum } \\
\text { (chaff) }\end{array}$ & & 445 & & & & \\
\hline $\begin{array}{l}\text { Triticum durum } \\
\text { (chaff) }\end{array}$ & & 344 & & & & \\
\hline Triticum dicoccum & & 8 & & & & \\
\hline Triticum monococcum & & 2 & & & & \\
\hline $\begin{array}{l}\text { Triticum - stubby } \\
\text { grains }\end{array}$ & & 352 & & & & 41 \\
\hline Triticum sp. & & 20 & & a & & \\
\hline Triticum (chaff) & & 5 & & & & \\
\hline cf. Triticum sp. & 1 & & & & & \\
\hline Cereals - undetermined & & 80 & & & & 4 \\
\hline $\begin{array}{l}\text { Cereals - undetermined } \\
\text { (chaff) }\end{array}$ & & 57 & & & & \\
\hline \multicolumn{7}{|l|}{ Other crops } \\
\hline Linum sp. & & 235 & & & & \\
\hline $\begin{array}{l}\text { Linum usitatissimum } \\
\text { (chaff) }\end{array}$ & & 226 & & & & \\
\hline Papaver somniferum & & 268 & & & & \\
\hline Pisum sativum & & 30 & & & & \\
\hline Vicia faba & & 8 & 2 & & 1 & \\
\hline \multicolumn{7}{|l|}{ Wild fruits } \\
\hline Corylus avellana & & & & & 1 & \\
\hline cf. Olea europaeae & & 1 & & & & \\
\hline cf. Pinus pinea & & 1 & & & & \\
\hline Pyrus sp. & & & & & 1 & \\
\hline Quercus sp. (cupule) & & & & & a & \\
\hline $\begin{array}{l}\text { Quercus sp. } \\
\text { (cotyledon) }\end{array}$ & & 1 (cf.) & 15 & a & 4 & \\
\hline Quercus sp.(hilum) & & 1 & & & & \\
\hline Quercus sp.(pericarp) & & & 1 & & & \\
\hline Rosaceae Maloideae & & & 2 & & & \\
\hline Rubus sp. & & 43 & & & & \\
\hline Sambucus nigra (fruit) & & 1 & & & & \\
\hline Sambucus nigra (seed) & & 41 & & & & \\
\hline
\end{tabular}

a Presence, no quantities available.

\section{Results and discussion}

\subsection{Bronze Age crops according to carpological data}

There are no Early Bronze Age sites with crops and those from the Middle Bronze Age are sparse (Table 3). This scenario concurs with the less number of Early Bronze Age settlements known in the region (Bettencourt, 1999, 2009). Although more Middle Bronze Age sites have been excavated it is not possible to know whether the scarcity of crop macroremains results from lack of systematic sampling strategies. In some sites, such as Sola and Tapada da Venda, among others, carbonized plant remains seemed to have been in fact scarce. On the other hand, the sites with more archaeobotanical data are those with more complex stratigraphic sequences, basically covering the Late Bronze Age.

Among all Middle Bronze Age sites, Freixo stands out because of the diversity and abundance of carpological remains found in the only pit yet fully analyzed. Cereals include naked and hulled varieties of barley and wheat. The latter comprise Triticum dicoccum and Triticum monococcum. The presence of rachis fragments allowed the identification of durum wheat (Triticum durum) among the naked wheat species. Both the typical T. aestivum/durum grains as well as "stubby grains" have been identified as the morphological types of the naked wheats. Furthermore, this single pit also provided remains of Linum usitatissimum (including capsules), Papaver somniferum, Pisum sativum and Vicia faba. Wild edible plants include acorns, Rubus and Sambucus nigra.

In contrast, the other Middle Bronze Age sites provided few carpological remains. In Tapada da Venda, Triticum "stubby grains" are found in most of the studied samples, but $H$. vulgare subsp. vulgare is also present (Bettencourt et al., 2007). In Sola (Phase IIb) few plant remains were found. Besides Vicia faba, we stress the presence of Panicum miliaceum, Corylus avellana and Pyrus (Bettencourt, 1999; Oliveira, 2000; Bettencourt et al., 2007). Data from Portecelo (Cano Pan and Vázquez Varela, 1991) is sparse, making it difficult to understand its relevance, while in Monte das Cabanas a single naked wheat grain, two faba beans and wild fruits (acorns and Maloideae) were found.

Besides carpological data, other archaeometric data provided relevant information regarding domestic plants consumed by Bronze Age communities. Residue analyses carried out at Devesa do Rei (Vedra, Galicia/Spain) led to the identification of phytoliths of Triticum aestivum/durum and starch of Triticeae in two vessels (Prieto Martínez et al., 2005). A fourth vessel provided evidence of flour made of Quercus acorns. Similar analyses in two vessels from the cist of A Forxa (Riós, Galicia/Spain) led to the identification of cereal phytoliths, yeast and starches affected by malting and enzymatic attack. This combination is interpreted as evidence of beer (Prieto Martínez et al., 2005, 2009). These were dated by radiocarbon from the mid-18th century to the beginning of 16th century cal BC (Prieto Martínez et al., 2009).

Despite the few data available, it is noted the presence of naked and hulled wheat, naked and hulled barley and an early presence of broomcorn millet. Non-cereal crops include pulses - Vicia faba and Pisum sativum - as well as poppy (Papaver) and flax (Linum). Acorns (Quercus) were being collected for food, as carpological remains and phytoliths demonstrate. Other wild fruits must have been collected. Nevertheless, the diversity suggested by this scenario is highly determined by the results obtained in Freixo. It is difficult to understand its regional significance but, at the same time, these results are highly demonstrative of how revealing a carpological study can be if proper sampling strategies are adopted as standard archaeological procedures.

Due to the great number of excavations done in North-western Portugal, there are significant Late Bronze Age sites with archaeobotanical remains (Table 4). Unfortunately, for many sites no quantitative data is provided in the publications. Still, it is clear that wheat (Triticum, $T$. aestivum/durum and Triticum "stubby grains") and H. vulgare subsp. vulgare are the prevailing cereals, now alongside with Panicum miliaceum. The most frequent pulse in Late Bronze Age sites is Vicia 
Table 4

Carpological remains in Late Bronze Age sites.

\begin{tabular}{|c|c|c|c|c|c|c|c|c|c|c|c|c|c|c|c|c|}
\hline & A Fontela & Canedotes & $\begin{array}{l}\text { Castelo de } \\
\text { Matos }\end{array}$ & $\begin{array}{l}\text { Coto da } \\
\text { Pena }\end{array}$ & Lavra - Baiao & Penalba & Penarrubia & $\begin{array}{l}\text { S. Juliao } \\
\text { (Ia) }\end{array}$ & $\begin{array}{l}\text { S. Juliao } \\
\text { (Ib Ic) }\end{array}$ & $\begin{array}{l}\text { S. Juliao } \\
\text { (Id) }\end{array}$ & $\begin{array}{l}\text { Santinha } \\
\text { (Phase 1) }\end{array}$ & $\begin{array}{l}\text { Santinha } \\
\text { (Phase 2) }\end{array}$ & $\begin{array}{l}\text { Senhora } \\
\text { da Guia }\end{array}$ & Torroso & $\begin{array}{l}\text { Vale } \\
\text { Ferreiro }\end{array}$ & Vasconcelos \\
\hline \multicolumn{17}{|l|}{ Cereals } \\
\hline Hordeum sp. & & & & & & & & & & & & 1 & & & & \\
\hline Hordeum vulgare var. nudum & & & & & & & & & & & & & $2 \mathrm{cf}$ & a & & \\
\hline $\begin{array}{l}\text { Hordeum vulgare subsp. } \\
\text { vulgare }\end{array}$ & & & a & & a & & & & & & & & & a & & \\
\hline Panicum miliaceum & 13 & & & & & $>1000$ & a & 2 & & & 4 & 4 & a & & & \\
\hline Panicum miliaceum (aggregated) & & & & & & & & & 1 & & & & & & & \\
\hline Panicum/Setaria & & & a & & & & & & & & & & & & & \\
\hline Triticum aestivum/durum & 54 & & & a & a & & & & & & & & & & & \\
\hline Triticum dicoccum & 1026 & & & & & 47,997 & & & & & & & & & & \\
\hline Triticum dicoccum (chaff) & 30 & & & & & 108 & & & & & & & & & & \\
\hline Triticum - stubby grains & & & & a & a & & & & & & & & & & & \\
\hline $\begin{array}{l}\text { Triticum sp. } \\
\text { Cereals - undetermined }\end{array}$ & 445 & a & a & & & & & 2 & & & 31 & 14 & & a & a & \\
\hline \multicolumn{17}{|l|}{ Other crops } \\
\hline Pisum sativum & & & & + & & & & & 1 & & & 2 & 81 & & & \\
\hline Vicia faba & & & a & a & a & & & & 1 & 7 & 13 & 3 & a & & & a \\
\hline \multicolumn{17}{|l|}{ Wild fruits } \\
\hline Pyrus sp. & & & & & a & & & & & & 1 & & & & & \\
\hline Quercus sp. (cupule) & & & & & & & & & 6 & & 1 & & & & & \\
\hline Quercus sp. (cotyledon) & & a & & a & & 103 & & & 22 & 8 & 142 & 10 & & & & \\
\hline Sorbus aucuparia & & & & & & & & & & & 1 & & & & & a? \\
\hline Vitis vinifera & & & a & & & & & & & & & & & & & \\
\hline
\end{tabular}

a Presence, no quantities available. 
faba, followed by Pisum sativum. Wild fruits, mostly acorns, appear to be relevant in some sites (Table 4). Finally, Triticum sp. phytoliths were found in a hand stone mill at Late Bronze Age levels from Os Pericos (Ribeira, Galicia/Spain) (Vilaseco Vázquez, 2012).

In Torroso (9th/7th centuries cal BC) both hulled and naked barley were cultivated (Dopazo Martínez, 1996; Dopazo Martínez et al., 1996). We must stress the presence of naked barley in Torroso in such late chronology as by this time it had already ceased to be a staple crop in many Iberian regions (Buxó and Piqué, 2008). It is possibly present in Senhora da Guia and it was also found in As Laias, in what seems to have been the oldest storage structure studied in the site up to now (Tereso et al., 2013). However, the chronology of this structure is problematic. Storage facilities made of wattle and daub are abundant in As Laias (Álvarez González and López González, 2000; Tereso et al., 2013). Most storage structures are from the Iron Age and the transition of the Era. However, one structure provided an older radiocarbon date. Unfortunately, the interval obtained showed a great time-span (CSIC1274: $2435 \pm 32,751-406$ cal BC at $2 \sigma$ ) and the radiocarbon date was obtained over unidentified charcoal remains. Considering large wood planks were used in the storage facilities, there is the possibility of the old wood effect. Thus we cannot exclude the eventuality of an Iron Age chronology. Moreover, this storage facility provided grains and chaff from Triticum spelta as well as grains from Avena, such as the Iron Age structures from the same site. The presence of Avena grains in Iron Age sites is very common. They were found in S. João de Rei II (Póvoa de Lanhoso, Portugal) (Dopazo Martínez, 1996; Bettencourt, 1999), Crastoeiro (Mondim de Basto, Portugal) (Dinis, 1993-1994, 2001 ) and in many other sites. Spelt has also been found in Iron Age sites in the region, such as Castrovite (Rey Castiñeira et al., 2011), Crastoeiro (Seabra, 2015) and Freixo/Tongobriga (López-Dóriga, 2015). However, as seen in Tables 3 and 4 no actual Bronze Age site provided any remains of these crops. The presence of two Avena sp. grains (and seven possible others) in Pit 15 in Freixo and a single grain in a Chalcolithic level of Castelo de Aguiar (Pinto da Silva quoted by Jorge, 1986) must not be overrated. They probably correspond to wild species, since the cultivation of oat at such early dates was not likely to have occurred, considering the data available for the rest of the Iberian Peninsula (Buxó and Piqué, 2008) and the domestic status cannot be ascertained in the absence of chaff. In the case of Castelo de Aguiar, contamination from more recent levels is also a possibility. Late Bronze Age (Silva, 2000), Iron Age and Roman occupations were found in the site (Batata et al., 2008).

Penalba, Penarrubia, and Vasconcelos are the most recent sites. In Penalba $2 \mathrm{~kg}$ of Panicum miliaceum and $70 \mathrm{~kg}$ of T. dicoccum were recovered (Aira Rodríguez et al., 1990). Penarrubia only provided Panicum miliaceum. The sparse presence of $T$. dicoccum in Northwestern Iberia must be noticed. This species is the prevailing crop in other Iberian regions (Buxó and Piqué, 2008), as well as in many European areas (Stika and Heiss, 2013; Primavera et al., 2015). Before the carpological analyses of Freixo and A Fontela that were unpublished until this study, the only Bronze Age site with T. dicoccum was Penalba. So, it is possible that further carpological studies will change the perspective regarding the role of hulled wheat in prehistoric times in Northwestern Iberia.

The Late Bronze Age is the first phase when we seem to have a consistence presence of millet in the region. A recent synthesis suggests that throughout Europe the transition from the Middle Bronze Age to the Late Bronze Age marks the transition of millets from minor to major crops in agricultural strategies (Stika and Heiss, 2013).

In Northwestern Iberia Panicum miliaceum is the only millet identified until now in Bronze Age contexts. Although for many years millet cultivation in the Iberian Peninsula was considered an Iron Age innovation, recent investigations, mainly in northern Spain and Portugal, testify for its presence as crop since, at least, the Middle Bronze Age (Bettencourt, 1999, 2003; Alonso, 2000; Buxó and Piqué, 2008).
There is a claim for the discovering of millet alongside with spelt in the Chalcolithic levels (3rd millennium cal BC) of Crasto de Palheiros (Murça), a site located in Northeast Portugal (Figueiral, 2008). Such early chronology is problematic. Millet grains (Panicum miliaceum and Panicum/Setaria) appear in Crasto de Palheiros only in one of the site's platforms both on Chalcolithic and Iron Age levels. 10 millet grains were found in the Chalcolithic levels and over 25,000 millet grains were recovered in the Iron Age ones (Figueiral, 2008). Chaff from $T$. spelta, together with abundant $T$. dicoccum/spelta grains (Figueiral, 2008), was recovered in another platform, in two depressions inside a Chalcolithic hut (Sanches, 2008). However, many disturbances to the Chalcolithic levels are confirmed by several radiocarbon dates obtained over wood charcoal, pointing out to much recent periods. These dates were considered erroneous by the archaeologist since they do not agree with the chronology of the artefacts recovered (Sanches, 2008) and must lead us to consider with caution data from that site. Direct radiocarbon dating of problematic material is needed so to confirm such early introduction of Panicum miliaceum and T. spelta. So far, a Chalcolithic chronology for the introduction of spelt in western Iberia would clearly contrast with the state of the art of this crop's history in the Iberian Peninsula (Buxó, 1997; Buxó et al., 1997; Tereso, 2012; Tereso et al., 2013). In what Panicum miliaceum is concerned, it has been found in several Bronze Age sites (Alonso, 2000; Buxó and Piqué, 2008; Moreno-Larrazabal et al., 2015) thus its cultivation seems to have begun in this period. Recent radiocarbon dates directly carried out on millet grains revealed the earliest chronologies in the European Bronze Age around the middle of the 2nd millennium cal BC (Motuzaite-Matuzeviciute et al., 2013).

In NW Iberia there is a single Middle Bronze Age site with millet Sola (Phase IIb) - and even there grains are occasional (Bettencourt, 1999, 2000b; Oliveira, 2000). Four Panicoideae grains have been identified in Freixo, but determination to species level has not been achieved and they might thus belong to a wild species. Recent isotopic analysis over human bones dated between 1890 and 1600 cal BC in the collective burial of Cova do Santo (Pardollán, Rubiá, Galicia/Spain), have failed to detect evidences of the consumption of C4 plants (López-Costas et al., 2015). It is interpreted as evidence that this Middle Bronze Age site precedes the introduction of millets (López-Costas et al., 2015), or it can suggest that the individuals found in the cave did not consume this cereal. Up to now, most Bronze Age sites with millet are located in Northern Portugal and the northernmost sites (in Northwestern Spain) are from the most recent phase of the Bronze Age. Further isotopic and carpological data are necessary to understand the history of millet cultivation in Northern and Western Iberia.

The presence of a spring cereal such as Panicum miliaceum in some Late Bronze Age settlements is highly relevant since it demonstrates the possibility of obtaining two crops a year. It is interesting to notice that it appears in a phase of increasing sedentarization and territorialisation and it can be in some way related to these changes (Bettencourt, 1999, 2000b; González-Ruibal, 2003). The cultivation of spring crops - as catch crops - is an important strategy to prevent famine in case of any setback affecting the winter crops (Vázquez Varela, 1993-1994; Fernández-Posse and Sánchez-Palencia, 1998). Still, although Panicum miliaceum is the first clear evidence for spring cultivation, one cannot exclude the possibility that other species such as naked wheat and hulled barley were used as spring crops. Weed functional studies must be carried out in order to address this matter (Bogaard et al., 2001, 2005; Jones et al., 2010), for which systematic soil sampling must become a regular strategy in excavations.

The growing relevance of millet and the little relevance of naked barley throughout the Bronze Age are the main differences regarding the previous period, the Calcolithic (Bettencourt, 1999; Bettencourt et al., 2007; Figueiral and Bettencourt, 2007; Tereso, 2012). In general, in Northwestern Iberia, during the Chalcolithic there is a preponderance of $H$. vulgare subsp. vulgare and $H$. vulgare var. nudum and naked wheat, namely the Triticum "stubby grains". Other crops, whether 
cereals, legumes, or even flax have little importance. This scenario comes, however, from crops found in a few sites, almost all located in Northern Portugal (Bettencourt, 1999; Tereso, 2012).

One must notice that the replacement of naked barley by hulled barley is a common scenario in other Iberian and European regions throughout the Bronze Age (Buxó and Piqué, 2008; Stika and Heiss, 2013). In Northern Portugal hulled barley seems to have been a very important crop already during the Chalcolithic. Although naked barley maintains its relevance, hulled barley appears more abundantly. Only in Buraco da Pala (Mirandela) is the naked variety more abundant than hulled barley, but even at this site there is a great increase of hulled barley when compared with previous levels (Ramil Rego and Aira Rodríguez, 1993; Sanches, 1997).

The small diversity of pulses - basically Vicia faba and Pisum sativum found in Bronze Age sites from Northwestern Iberia contrasts with Mediterranean Iberia and other European regions (Buxó and Piqué, 2008; Stika and Heiss, 2013). For the moment it is not possible to know whether this small diversity is related to cultural or bioclimatic factors, eventual preservation biases or sampling problems. Regarding other non-cereal crops, only poppy and flax were recorded. All Bronze Age remains from these species came from the pit of Freixo. Flax had been previously recorded in the study-area in the Chalcolithic site of Bitarados (Esposende, Portugal) (Bettencourt et al., 2007) but it was also recovered in Northeast Portugal, namely in Buraco da Pala (Ramil Rego and Aira Rodríguez, 1993; Sanches, 1997). Poppy seeds had not been recovered in any prehistoric site in the study-area before the analyses of Freixo. However, they were recovered in the Chalcolithic levels of Buraco da Pala (Ramil Rego and Aira Rodríguez, 1993; Sanches, 1997) and Castelo Velho (Vila Nova de Foz Coa) (Figueiral and Jorge, 2008), both in Northeast Portugal.

Quercus spp. acorns are the only wild fruits consistently present throughout the time-span covered here and are the plant remains that were recovered in more sites. In fact, they were found in several other sites where no crops were recovered (Bettencourt, 1999), thus not appearing in Tables 3 and 4. Archaeobotanical sampling is occasional in the region although archaeobotanical materials have been recorded since the first excavations in the 19th century (Sarmento, 1903). Not surprisingly, in earlier excavations the more abundant carpological materials found corresponded to acorns, most probably due to their size. Thus any comparison between the number of sites with crops and sites with acorns cannot be reliable.

Vitis was found in a single site - Castelo de Matos - and a radiocarbon date was obtained from one seed, confirming its Late Bronze Age chronology but no biometric studies were carried out. Early archaeobotanical data suggest that this species is native to the region. Pips have been found in the 3rd millennium levels of Buraco da Pala (Mirandela) (Ramil Rego and Aira Rodríguez, 1993) and charcoal was retrieved in the Neolithic funerary monument of Mamoa da Arcã (Mirandela, Portugal) (Figueiral and Sanches 1998-1999). Thus, it is likely that grapes were collected from the wild during the Bronze Age.

Overall, the gathering of wild fruits, particularly acorns, was probably an important complement to agriculture. The exploitation of wild resources by fully agricultural communities fitted in a strategy of resource optimization since they were very abundant in the region. Such strategy is also clear in the zooarchaeological record.

Zooarchaeological evidence is very sparse due to poor preservation conditions, but the management of diversified resources throughout the Bronze Age is suggested by the presence of domestic and wild terrestrial animals, as well as fish and molluscs in few sites (Silva, 1986; Antunes, 1991; Bettencourt, 1999; Fernández Rodríguez, 2000; Férnandez Rodríguez, 2010; Fernández Rodríguez and Pérez Ortiz, 2007; Bettencourt et al., 2007). In the Middle Bronze Age levels of the Guidoiro Areoso (Illa de Arousa, Pontevedra, Spain), Bos taurus, Ovis aries/Capra hircus and Sus domesticus predominate and fish and birds are also found (Fernández Rodríguez and Pérez Ortiz, 2007). In the Middle Bronze Age levels of Pala da Vella (Rubiá, Ourense, Spain) the domestic assemblage is similar and evidence of hunting activities are also found (Cervus elaphus, Capreolus capreolus, Lepus capensis, among others) (Fernández Rodríguez, 2000 and Fernández Rodríguez and Pérez Ortiz, 2007). In Late Bronze Age sites from Northwestern Portugal (Barbudo, S. Julião and Coto da Pena) the same domestic species were found (see synthesis in Bettencourt, 1999). The collection of molluscs is testified in the Late Bronze Age levels of the coastal settlement of Coto da Pena (Silva, 1986), in the Early Bronze Age pit of Areias Altas (Cabral, 2010) and in the Middle Bronze Age site of Guidoiro Areoso (Rodríguez López in Rey García, 2011).

\subsection{Agriculture and settlement pattern in the Bronze Age}

During the Early and Middle Bronze Ages, human communities seem to continue a previous tendency to occupy several different areas in low and mid altitudes: small hills, plateaus and spurs near the valleys, usually at low altitudes (Bettencourt, 1999, 2000c, 2003, 2005b, 2009, 2013a; Bettencourt et al., 2007). More permanent settlements coexisted with other smaller and seasonally occupied places (Bettencourt, 2005b, 2009, 2013a; Parcero Oubiña and Ayán Vila, 2009). Some apparently permanent settlements are associated to necropolis (Bettencourt, 1999, 2003, 2008, 2009, 2010a, 2010b, 2013a; Parcero Oubiña and Ayán Vila, 2009).

Our tentative interpretation suggests this settlement pattern, profoundly related to the valleys, may have beneficiated from the E4 erosion event identified by P. Ramil Rego (1993b) and Martínez Cortizas et al. (1993), mentioned by Muñoz Sobrino et al. (2005), as it coincides with its last stages. In fact, it is possible that, in some areas, Late Chalcolithic and Early/Middle Bronze Age communities chose settlement strategies, which allowed them to take advantage of the new soils existing in the valleys. If so, changes in the landscape acted as an opportunity to increase productivity. Detailed and oriented geomorphological and archaeological studies should be done in order to test this possibility.

An increase in productivity is suggested by the increasing size of the settlements and the more frequent presence of pits, some of them probably used as storage facilities in the Middle Bronze Age. In some settlements of this period, such as Monte de Cabanas (Vigo, Spain) (unpublished), Monte Buxel, (Pazos de Borbén, Spain) (Criado Boado et al., 2000; Lima Oliveira and Prieto Martínez, 2002), Monte Calvo (Baião, Portugal) (Bettencourt, 2013a; Martín Seijo et al., 2012), Freixo (Marco de Canaveses), (unpublished), Pego (Braga, Portugal) (Sampaio et al., 2008; Sampaio, 2014), Quinta do Amorim, Braga (Sampaio, 2014), Sola (Phase IIb) (Bettencourt, 2000b), Quinta do Rapido (Barcelos, Portugal) (Bettencourt, 2009, 2013a); Lavra (Matosinhos, Portugal) (Bettencourt and Fonseca, 2011), Cimalha (Felgueiras, Portugal) (Bettencourt, 2009, 2013a; Vieira, 2014), Tapada da Venda (Celorico de Basto, Portugal) (Bettencourt et al., 2007), Corgo (Vila do Conde, Portugal) (Bettencourt, 2009, 2013a; Botelho, 2013; Vieira, 2014) and Bouça do Frade (Baião, Portugal) (Jorge, 1988; Bettencourt, 2003) several of these pits were excavated. However, only in Monte das Cabanas, Freixo, Tapada da Venda and Sola (Phase IIb) were crop macroremains found inside the pits and even then only in Freixo part of the assemblage was found in primary deposition. In Freixo, the fill of the studied pit (Pit 15) was microestratified and its lower layer, very thin and covering the lower part of the walls and bottom, was rich in sprouted cereal (mostly naked wheat but also barley) grains. This allowed López-Dóriga (2015) to propose these remains were probably the remnants of a stored product which had germinated and remained adhered to the pit borders upon emptying, becoming later charred upon disinfection of the pit. The charred macroremain assemblages present in the other fill deposits within the pit were radically different in composition and were identified as probable food processing by-products. In addition, below the mouth of the pit two indentures in the wall for receiving a possible lid were tentatively identified.

In other pits in Freixo and in the other sites sites, the plant macroremains were found in association with charcoal and artefacts, 
demanding caution in their interpretation as the result of actual storage (Bettencourt, 2000a, 2000b; Bettencourt et al., 2007). In Sola (Phase IIb) cork was found inside one pit with acorns, suggesting it was used to add further protection against humidity. Thus, in the other sites, the interpretation of the pits as storage facilities is based on their typology and their stratigraphic characteristics rather than the presence of carpological remains. Since seldom are soil samples recovered during the excavations, it is difficult to assess the real importance of pits as storage facilities in the Middle Bronze Age. This is particularly relevant considering that in some sites, other interpretations (tombs, ritual contexts, among others) were proposed for similar structures, according to their typology and fills (Bettencourt, 1999, 2000a, 2008, 2009; Parcero Oubiña, 1997; Criado Boado et al., 2000; Fábregas Valcarce, 2001; Prieto Martínez et al., 2009; Luz, 2010; Cabral, 2010).

Archaeological excavations in Late Bronze Age settlements in the area also point to high levels of productivity, since pits, usually interpreted as storage facilities, continue to be very abundant in some settlements such as Bouça do Frade (Jorge, 1988), Lavra (Phase II) (Marco de Canaveses, Portugal) (Sanches, 1988, 1995), Santinha (Phases I and II) (Bettencourt, 1999, 2001) and Pego (Sampaio et al., 2008; Sampaio, 2014). Santinha (Phase II) is a paradigmatic site, since in its upper platform several pits were found inside a hut delimited by post-holes and some stones in what was interpreted as a communal storage area (Bettencourt, 1999, 2001). Crops were found inside pits in Santinha, together with other debris, such as charcoal fragments and ceramics. On the other hand, in Penalba, storage seems to have occurred in vessels above-ground (Aira Rodríguez et al., 1990).

Regarding settlement strategies, investigations confirm that settlement diversification occurred already in the Late Bronze Age, at least in some areas (Jorge, 1988; Bettencourt, 1999, 2000c, 2009, 2013a, $2013 \mathrm{~b})$. Settlements in the low hills of great valleys, in the plateaus of medium altitude and mountain camps are found alongside with settlements in the valleys and settlements in mid/high-altitude spurs controlling the more important river basins (Jorge, 1988; Bettencourt, 2000c, 2009, 2013a, 2013b). Some of these settlements have delimitation structures such as embankments or wooden palisades but actual fortification is rare during this period (Jorge, 1995; Bettencourt, 1995, 2005a, 2009).

Rather than diverse settlement strategies, there seems to be a strategy based on the diversity of settlements. This implies that some kind of network connection existed between the settlements, as suggested by Bettencourt (1999, 2000c, 2009, 2013a, 2013b). This greater connectivity may have led to an increased territoriality based on the complementarity between settlements, according to their strategic location near specific ecosystems and/or soils. This strategy implied a more profound use of the territory thus a greater pressure over it.

In sum, crops available in Northwestern Iberia during the Late Bronze Age probably included winter and spring crops with different demands in terms of soils, water and sun exposure - functional diversity - which makes us consider a system based on the complementarity between different species which would allow the communities to fully explore their territory within a network of interconnected places. This fits the interpretative models defined for Northwestern Iberia (Bettencourt and Sampaio, in press), the Northwest of Portugal (Bettencourt, 2009, 2013a, 2013b) and, more in particular, for the Cávado basin (Bettencourt, 1999, 2000b), Leça basin (Bettencourt, 2010b), or Ave basin (Sampaio, 2014).

\section{Conclusions: crops, societies and environment from the end of the 3rd to the mid-1st millennia BC}

The Bronze Age was a time of increasing pressure over the environment. As mentioned before, such pressure can be deduced from several palaeoenvironmental studies, such as the abundant palynological sequences (Ramil Rego, 1992; Ramil Rego et al., 1998;
Muñoz Sobrino et al., 1997, 2001, 2004, 2007; Mighall et al., 2006; López-Merino et al., 2011, 2012) and anthracological studies (Figueiral, 1990, 1993, 1996; Figueiral and Bettencourt, 2004; Martín Seijo et al., 2011; Martín Seijo, 2013; Martín-Seijo et al., 2015 ) carried out in the region. All these different approaches document a significant decrease in forest cover occurring in Late Prehistoric times, particularly since the Bronze Age. This trend has been identified both in coastal and continental contexts and is frequently attributed to changes in human production strategies.

The archaeological record allows us to further understand the technological and social context in which environment and agriculture changed. It is clear that this process occurred at the same time, and probably related to, an increase in settlement size which led to an increasing demand for construction wood, the further development of copper metallurgy and the emergence and development of bronze metallurgy since the Middle Bronze Age (Bettencourt, 2005a, 2005b, 2009, 2010b, 2013a, 2013b; Comendador-Rey et al., 2008; Sampaio, 2014). As forests decreased, agricultural activities became more important, societies became more sedentary and connectivity between human communities was enhanced changing the local settlement patterns. This probably coincides with an increase in demography and surplus production (Bettencourt, 2009, 2010b).

The carpological data from Bronze Age sites in Northwestern Iberia provide relevant insights regarding agriculture in these changing times. The Middle Bronze Age carpological record documents the introduction of Panicum miliaceum in the region. This is a versatile spring crop with a very short vegetative cycle that may have implied changes in subsistence strategies. Hulled and naked varieties of wheat and barley are documented, as well as peas, faba bean, flax and poppy.

Early and Middle Bronze Age settlements are found in different areas, from the coastal platform to the more continental areas. Human communities show preferences for occupying small hills mainly positioned in lowlands and near the valleys, which could have had easy access to good soils. This may have been important to support population growth. Pits may have been the main type of storage facility during all the Bronze Age. This does not exclude the possibility of other storage facilities, archaeologically less visible (Sigaut, 1988), being used.

Wheat and millet are the crops found in more Late Bronze Age sites but changes in the archaeological record are more conspicuous. Since the end of the 2nd millennium and the beginning of the 1st millennium cal BC, the existence of settlements in distinct and, probably, complementary locations suggests an increase in territorialisation and an improvement in settlements' connectivity. Enhanced productivity is suggested by the abundant storage facilities in several settlements (Bettencourt, 1999). In this sense, agricultural systems could have been based on the complementarity of different crops and different but connected - settlements positioned in distinct locations, exploring distinct resources (Bettencourt, 1999, 2000c, 2005a, 2009, 2013a).

These new, more interconnected and productive social-ecological systems led to new and greater pressure over the environment. This was a crucial stage in the consolidation of the agrarian system.

Overall, the changes here described marked a trend in the processes that drive landscape evolution: the emergence of new productive social-ecological systems that, as today, were characterized by intertwined structures and processes linked across spatial and temporal scales (e.g. systems described by Walker et al., 2006). The continuing anthropogenic changes that mark the onset and development of productive activities throughout prehistoric times represent a new trend in the environmental history of the region and they document a shift in the human strategies of exploring the resources, towards ever more complex and unsustainable social ecological systems as suggested by the increasing deforestation and soil erosion. 


\section{References}

Aira Rodríguez, M., Ramil Rego, P., Álvarez Nuñez, A., 1990. Estudio paleocarpológico realizado en el Castro de Penalba (Campolameiro, Pontevedra. España). Botanica Complutensis 16, 81-89.

Aira Rodríguez, M.J., Ramil-Rego, P., 1995. Datos paleobotánicos del Norte de Portugal (Baixo Minho). Estudio polínico y paleocarpológico. Lagascalia 18, 25-38.

Alonso, N., 2000. Registo arqueobotánico de Cataluña occidental durante el II y I milenio A.N.E. Complutum 11, 221-238.

Álvarez González, Y., López González, L., 2000. La secuencia ultural del asentamiento de Laias: evolución espacial y funcional del poblado. In: Jorge, V. (Ed.), Actas do $3^{\circ}$ congresso de Arqueología Peninsular, (Vila Real, 1999). ADECAP, Porto, pp. 523-532.

Álvarez Nuñez, A., 1986. Castro de Penalba: Campaña de excavación de 1983. Serie Arqueoloxia/Memorias 4. Xunta de Galicia.

Antunes, M., 1991. Povoado proto-histórico de S. Julião (Vila Verde): elementos arqueozoológicos. Cadernos de Arqueologia 8-9 (2ª́rie), pp. 237-239.

Arias Vilas, F., 1979. El Castro de Penarrubia (Lugo) y la novedad de su datación por C14. XV Congreso Arqueológico Nacional (Lugo, 1977), pp. 613-622.

Batata, C., Borges, N., Correia, H., Sousa, A.d., 2008. Carta arqueológica do concelho de Vila Pouca de Aguiar, Câmara Municipal de Vila Pouca de Aguiar/Ozecarus. Serviços Arqueológicos Lda., Vila Pouca de Aguiar.

Bettencourt, A.M.S., 1995. Dos inícios aos finais da Idade do Bronze no Norte de Portugal. In: Cordeiro, I., Silva, I., Fernandes, M.A. (Eds.), A Idade do Bronze em Portugal. Discursos de poder, Secretaria de Estado da Cultura, Instituto Português de Museus, Museu Nacional de Arqueologia, Lisboa, pp. 110-115.

Bettencourt, A.M.S., 1999. A Paisagem e o Homem na Bacia do Cávado durante o II e o I milénio AC. PhD Thesis. Instituto de Ciências Sociais, Universidade do Minho, Braga.

Bettencourt, A.M.S., 2000a. Estações da Idade do Bronze e Inícios da Idade do Ferro da Bacia do Cávado (Norte de Portugal). Cadernos de Arqueologia - Monografias 11. Universidade do Minho/Instituto de Ciências Sociais, Braga.

Bettencourt, A.M.S., 2000b. O Povoado da Idade do Bronze da Sola, Braga, Norte de Portugal. Cadernos de Arqueologia - Monografias 9. Universidade do Minho/Instituto de Ciência Sociais, Braga.

Bettencourt, A.M.S., 2000c. O vale do Cávado (Norte de Portugal) dos finais do III milénio aos meados do I milénio AC: sequências cronológico-culturais. In: Jorge, V.O. (Ed.), Actas do $3^{\circ}$ Congresso de Arqueologia Peninsular, Setembro 1999. ADECAP, Porto, pp. 79-93.

Bettencourt, A.M.S., 2000d. O povoado de S. Julião, Vila Verde, Norte de Portugal, na Idade do Bronze e na Transição para a Idade do Ferro. Cadernos de Arqueologia - Monografias 10. Universidade do Minho/Instituto de Ciências Sociais, Braga.

Bettencourt, A.M.S., 2001. O povoado da Santinha, Amares, Norte de Portugal. nos Finais da Idade do Bronze, Cadernos de Arqueologia - Monografias 12. Universidade do Minho, Instituto de Ciências Sociais, Braga.

Bettencourt, A.M.S., 2003. Plant and animal husbandry in the second millennium BC in northern Portugal. J. Iber. Archaeol. 5, 199-208.

Bettencourt, A.M.S., 2005a. O que aconteceu às populações do Bronze Final do Noroeste de Portugal, no segundo quartel do I milénio AC, e quando começou, afinal, a Idade do Ferro? Actas do Colóquio Internacional Castro, um Lugar para Habitar (2004) 11. Cadernos do Museu, Câmara Municipal de Penafiel, pp. 25-40

Bettencourt, A.M.S., 2005b. The Bronze Age in north-west Portugal/A Idade do Bronze no Noroeste de Portugal. In: Silva, L., Mineiro, C. (Eds.), D. Diodo de Sausa. Regional Museum of Archaeology. Guide/D. Diogo de Sousa. Museu Regional de Arqueologia. Roteiro, Instituto Português dos Museus, Lisboa, pp. 36-41.

Bettencourt, A.M.S., 2008. Life and death in the Bronze Age of the NW of Iberian Peninsula. In: Fahlander, F., Oestigaard, T. (Eds.), The Materiality of Death: Bodies, Burials, Beliefs. British Archaeological Reports, Oxford, pp. 99-104.

Bettencourt, A.M.S., 2009. A Pré-história do Minho. Do Neolítico à Idade do Bronze. In: Pereira, P. (Ed.), Minho. Traços de Identidade. Conselho Cultural da Universidade do Minho, Braga, pp. 70-120.

Bettencourt, A.M.S., 2010a. La Edad del Bronce en el Noroeste de la Península Ibérica: un análisis a partir de las prácticas funerárias. Trab. Prehist. 67, 139-173.

Bettencourt, A.M.S., 2010b. Comunidades pré-históricas da bacia do Leça: do predador "nómada" ao agricultor sedentário. In: Varela, J., Pires, C. (Eds.), O Rio da Memória: Arqueologia no Território do Leça. Câmara Municipal de Matosinhos, Matosinhos, pp. 33-88.

Bettencourt, A.M.S., 2013a. The Prehistory of the Northwestern Portugal. CEIPHAR/ CITCEM, Braga/Tomar.

Bettencourt, A.M.S., 2013b. O Bronze Final no Noroeste português. Uma rede complexa de lugares. Estudos Arqueológicos de Oeiras 20, 145-162.

Bettencourt, A.M.S., Fonseca, J., 2011. O povoado da Idade do Bronze de Lavra, Matosinhos. Contributos para o estudo do Bronze Médio do litoral Norte, Centro de Investigação Transdisciplinar. Cultura, Espaço e Memória. CITCEM/Junta Freguesia de Lavra, Matosinhos.

Bettencourt, A.M.S., Dinis, A., Figueiral, I., Rodrigues, A., Cruz, C., Silva, I., Azevedo, M. Barbosa, R., 2007. A ocupação do território e a exploração de recursos durante a Pré-história Recente do Noroeste de Portugal. In: Jorge, S., Bettencourt, A.M.S. Figueiral, I. (Eds.), A Concepção das paisagens e dos espaços na Arqueologia da Península Ibérica, Actas do IV Congresso de Arqueologia Peninsular (2004), Promontoria Monográfica 08. Universidade do Algarve, Faro, pp. 149-164.

Bettencourt, A.M.S., Dinis, A., Silva, I., Cruz, C., Pereira, J., 2002. A estação arqueológica da Tapada da Venda, Pedroso, Celorico de Basto (Norte de Portugal): primeiras impressões das escavações de 2001, Portugalia 23. Nova Série 187-200.

Bettencourt, A.M.S., Rodrigues, A., SilvaI, S.E., Cruz, C., Dinis, A., 2005. The ceremonial site of Vale Ferreiro, Fafe, in the context of the Bronze Age in Northwest Portugal. J. Iber. Archaeol. 7, 159-175.
Bettencourt, A.M.S., Sampaio, H., in press. The Middle and the beginning of the Late Bronze Age in the northwestern Iberia Le Bronze Moyen et l'origine du Bronze Final en Europe occidentale (XVIIe-XIIIe s. av. J.-C.), Actes du colloque "Bronze 2014", l'APRAB.

Bogaard, A., Jones, G., Charles, M., 2005. The Impact of Crop Processing on the Reconstruction of Crop Sowing Time and Cultivation Intensity from Archaeobotanical Weed Evidence. 14. Vegetation History and Archaeobotany, pp. 505-509.

Bogaard, A., Jones, G., Charles, M., Hodgson, J.G., 2001. On the archaeobotanical inference of crop sowing time using the FIBS method. J. Archaeol. Sci. 28, 1171-1183.

Botelho, I., 2013. O sítio do Corgo. Uma estação da Idade do Bronze em Vila do Conde. In: Arnaud, J., Martins, A., Neves, C. (Eds.), Arqueologia em Portugal. 150 anos. Associação dos Arqueólogos Portugueses, Lisboa, pp. 581-589.

Buxó, R., 1997. Arqueología de las Plantas. Crítica (Barcelona).

Buxó, R., Alonso, N., Canal, D., Echave, C., González, I., 1997. Archaeobotanical Remains of Hulled and Naked Cereals in the Iberian Peninsula. 6. Vegetation History and Archaeobotany, pp. 15-23.

Buxó, R., Piqué, R., 2008. Arqueobotánica. Los usos de las plantas en la península Ibérica. Ariel, Barcelona.

Cabral, J., 2010. O depósito de conchas do sítio arqueológico das "Areias Altas" (Porto, Portugal). Estudo morfológico e morfométrico das conchas inteiras de moluscos. Férvedes 6, 73-82.

Canha, A. 2002. Canedotes - Povoado do Bronze Final do Alto Paiva, 2 vols. MSc Thesis University of Porto, Porto.

Cano Pan, J., Vázquez Varela, J., 1988. Portecelo, un yacimiento de la Edad del Bronce. Trabalhos de Antropologia e Etnologia 28, 181-187.

Cano Pan, J., Vázquez Varela, J., 1991. In: Queiroga, F., Dinis, A. (Eds.), La economía de un yacimiento del comienzo del Bronce Final: Portecelo (O Rosal, Pontevedra). Paleoecologia e Arqueologia Centro de Estudos Arqueológicos Famalicenses, Vila Nova de Famalicão, pp. 205-208.

Carrión, Y., Kaal, J., López-Sáez, J.A., López-Merino, L., Martínez Cortizas, A., 2010. Holocene vegetation changes in NW Iberia revealed by anthracological and palynological records from a colluvial soil. The Holocene 20, 53-66.

Comendador-Rey, B., Reboreda-Morillo, S., Kockelmann, W., Macdonald, M., Bell, T. Pantos, M., 2008. Early bronze technology at Land's End, North Western Iberia. In Paipetis, S.A. (Ed.), Science and Technology in Homeric Epics 6. Springer Netherlands, pp. 113-131.

Criado Boado, F., Amado Reino, X., Martínez López, M.C., Cobas Fernández, I., Parcero Oubiña, C., 2000. Programa de corrección del impacto arqueológico de la gasificación de Galicia. Un ejemplo de gestión integral del património arqueológico. Complutum $11,63-85$.

Cruz, D., 1997. A necrópole do Bronze Final do "Paranho" (Molelos, Tondela, Viseu). Estudos Pré-históricos 5, 85-109.

da Silva, A.P., 1976. Carbonized grains and plant imprints in ceramics from the castrum of Baiões (Beira Alta, Portugal). Folia Quaternaria 47, 3-9.

da Silva, A.P., 1988. A paleoetnobotânica na arqueologia portuguesa. Resultados desde 1931 a 1987. In: Queiroga, F., Sousa, I., Oliveira, C. (Eds.), Palaeocologia e Arqueologia. Câmara Municipal de Vila Nova de Famalicão, Vila Nova de Famalicão, pp. 13-29.

Dinis, A., 1993-1994. Contribuição para o estudo da Idade do Ferro em Basto: o Castro do Crastoeiro. Cadernos de Arqueologia 10-11, 261-278.

Dinis, A., 2001. O povoado da Idade do Ferro do Crastoeiro (Mondim de Basto, Norte de Portugal). Cadernos de Arqueologia - Monografias 13. Universidade do Minho, Instituto de Ciências Sociais, Braga.

Dopazo Martínez, A., 1996. La dieta vegetal del Noroeste Ibérico durante el Holoceno. Una aproximación a través del análisis paleocarpológico. Graduation Thesis. Universidade de Santiago de Compostela.

Dopazo Martínez, A., Fernández Rodríguez, C., Ramil-Rego, P., 1996. Arqueometría aplicada a yacimientos Galaico-romanos del NW Penínsular: valoración de la actividad agrícola y ganadera. In: Ramil-Rego, P., Fernández Rodríguez, C. Rodríguez Guitían, M. (Eds.), Biogeografia Pleistocena - Holocena de la Península Ibérica. Xunta de Galicia, Santiago de Compostela, pp. 317-332.

Fábregas Valcarce, R. (Ed.), 1998. A Idade do Bronce en Galicia: Novas perspectivas, Ediciós do CastroSada (A Coruña).

Fábregas Valcarce, R., 2001. Los petroglifos y su contexto: un ejemplo de la Galicia meridional. Instituto de Estudios Vigueses, Vigo.

Fábregas Valcarce, R., Bradley, R., 1995. El silencio de las fuentes: práticas funerarias en la Edad del Bronce del Noroeste y su contexto europeo. Complutum 6, 153-166.

Fábregas Valcarce, R., Martínez Cortizas, A., Blanco Chao, R., Chesworth, W., 2003. Environmental change and social dynamics in the second-third millennium BC in NW Iberia. J. Archaeol. Sci. 30, 859-871.

Fábregas Valcarce, R., Ruíz-Gálvez Priego, M.L., 1997. El Noroeste de la Península Ibérica en el $\mathrm{III}^{\circ}$ y $\mathrm{II}^{\circ}$ milenios AC: propuestas para una síntesis. Sagvntvm 30, 191-216.

Fernández Rodríguez, C., 2000. Los macromamíferos en los yacimientos arqueológicos de Noroeste peninsular: un estudio económico. PhD Thesis. Facultade de Xeografía e Historia. Universidade de Santiago de Compostela., Santiago de Compostela.

Férnandez Rodríguez, C., 2010. Faunas arqueológicas en el Noroeste de la Península Ibérica. In: Bettencourt, A.M.S., Alves, M.I.C., Monteiro-Rodrigues, S. (Eds.), Variações Paleoambientais e Evolução antrópica. Associação Portuguesa para o Estudo do Quaternário-APEQ/Centro de Investigação Transdisciplinar. Cultura, Espaço e Memória-CITCEM, Braga, pp. 97-112.

Fernández Rodríguez, C., Pérez Ortiz, L., 2007. Caza y domesticación en el Noroeste de la Península Ibérica durante la Prehistoria. Datos arqueozoológicos. In Jorge, S., Bettencourt, A.M.S., Figueiral, I. (Eds.), A Concepção das paisagens e dos espaços na Arqueologia da Península Ibérica, Actas IV Congresso de Arqueologia Peninsular (2004), Promontoria Monográfica, 8. Universidade do Algarve, Faro, pp. 165-176. 
Fernández-Posse, M., Sánchez-Palencia, F., 1998. Las comunidades campesinas en la cCultura Castreña. Trab. Prehist. 55, 127-150.

Figueiral, I., 1990. Le Nord-Ouest du Portugal et les modifications de l'ecosysteme, du Bronze final a l'epoque romaine, d'apres l'anthracoanalyse de sites archeologiques. $\mathrm{PhD}$ Thesis. Université des Sciences et Techniques du Languedoc, Montpellier.

Figueiral, I., 1993. Charcoal analysis and the vegetational evolution of North-West Portugal. Oxf. J. Archaeol. 12, 209-222.

Figueiral, I., 1996. Wood resources in north-west Portugal: their availability and use from the Late Bronze Age to the Roman period. 5. Vegetation History and Archaeobotany, pp. 121-129.

Figueiral, I., 2008. O Crasto de Palheiros (Murça, NE Portugal): a exploração dos recursos vegetais durante o III/inícios do II milénio AC e entre o I milénio AC e o séc. II DC. In: Sanches, M.J. (Ed.), O Crasto de Palheiros. Fragada do Castro. Murça - Portugal, Município de Murça, Murça, pp. 79-108.

Figueiral, I., Sanches, M.J., 1998/1999. A contribuição da antracologia no estudo dos recursos florestais de Trás-os-Montes e Alto Douro durante a Pré-história Recente. 19-20. Nova Série, Portugália, pp. 71-101.

Figueiral, I., Bettencourt, A.M.S., 2007. Estratégias de exploração do espaço no Entre Douro e Minho desde os finais do IV aos meados do I milénio AC. In: Jorge, S., Bettencourt, A.M.S., Figueiral, I. (Eds.), A Concepção das paisagens e dos espaços na Arqueologia da Península Ibérica, Actas do IV Congresso de Arqueologia Peninsular (2004), Promontoria Monográfica 8. Universidade do Algarve, pp. 177-187.

Figueiral, I., Bettencourt, A.M.S., 2004. Middle/Late Bronze Age plant communities and their exploitation in the Cavado Basin (NW Portugal) as shown by charcoal analysis: the significance and co-occurrence of Quercus (deciduous) Fabaceae. 13. Vegetation History and Archaeobotany, pp. 219-232.

Figueiral, I., Jorge, S.O., 2008. Man-made landscapes from the third-second millennia BC: the example of Castelo Velho (Freixo de Numão, North-East Portugal). Oxf. J. Archaeol. 27, 119-133.

González-Ruibal, A., 2003. Arqueología del Primer Milenio a.C. en el Noroeste de la Península Ibérica. PhD Thesis. Complutense University of Madrid, Madrid.

Hillman, G., Mason, S., de Moulins, D., Nesbitt, M., 1996. Identification of archaeological remains of wheat: the 1992 London workshop. Circaea 12, 195-210.

Jacomet, S., 2006. Identification of cereal remains from archaeological sites, $2^{\mathrm{a}}$ edição ed. IPAS, Basel University, Archaeobotany Lab.

Jones, G., Charles, M., Bogaard, A., Hodgson, J., 2010. Crops and weeds: the role of weed functional ecology in the identification of crop husbandry methods. J. Archaeol. Sci. 37, 70-77.

Jordá Pardo, J.F., Rey Castiñeira, J., Picón Platas, I., Abad Vidal, E., Marín Suárez, C., 2009. Radiocarbon and chronology of the Iron Age hillforts of Northwestern Iberia. In: Karl, R., Leskovar, J. (Eds.), Interpretierte Eisenzeiten. Fallstudien, Methoden, Theorie. Tagungsbeiträge der 3 Linzer Gespräche zur interpretativen Eisenzeitarchäologie. Studien zur Kulturgeschichte von Oberösterreich. Oberösterreichischen Landesmuseum, Linz, pp. 81-98.

Jorge, S., 1986. Povoados da Pré-História Recente da Região de Chaves-Vila Pouca de Aguiar (Trás-os-Montes Ocidental): Bases paro o Conhecimento do $\mathrm{III}^{\circ}$ e Princípios do $\mathrm{II}^{\circ}$ Milénios a. C. no Norte de Portugal. Faculdade de Letras, Universidade do Porto, Porto.

Jorge, S., 1988. O Povoado da Bouça do Frade (Baião) no Quadro do Bronze Final do Norte de Portugal. GEAP, Porto.

Jorge, S., 1995. O Bronze Final no Norte de Portugal. Uma história em discussão. $01^{\circ}$ Milénio a.C. no Noroeste Peninsular. In: Redentor, A. (Ed.), A fachada Atlântica e o Interior. Parque Nacional de Montesinho, Bragança, pp. 13-22.

Jorge, S., 1996. Regional diversity in the Iberian Bronze Age - on the visibility and opacity of the archaeological record. Trabalhos de Antropologia e Etnologia 36, 193-214.

Jorge, S., Jorge, V., 2006. Sociedades hierarquizadas, sociedades estratificadas? O Bronze Final. In: Almeida, C.A.B. (Ed.), História do Douro e do Vinho do Porto. História Antiga da Região Duriense, Edições Afrontamento, Porto, pp. 164-187.

Kaal, J., Carrión Marco, Y., Asouti, E., Martín Seijo, M., Martínez Cortizas, A., Costa Casáis, M., Criado Boado, F., 2011. Long-term deforestation in NW Spain: linking the Holocene fire history to vegetation change and human activities. Quat. Sci. Rev. 30, 161-175.

Kalb, P., 1974-1977. Uma data de C-14 para o Bronze Atlântico, O Arqueólogo Português 7-9 (3â série). pp. 141-144.

Kalb, P., 1980. O 'Bronze Atlântico’ em Portugal. Seminário de Arqueologia do Noroeste Peninsular (Guimarães, 1980), pp. 113-120.

Lillios, K.T., Blanco-González, A., Drake, B.L., López-Sáez, J.A., 2016. Mid-late Holocene climate, demography, and cultural dynamics in Iberia: a multi-proxy approach. Quat Sci. Rev. 135, 138-153.

Lima, A., 2014. Tongobriga/Santa Maria do Freixo. Projecto de Investigação Arqueológica para o Quadriénio 2014/17, Porto, Direcção Regional de Cultura do Norte (Unpublished project paper).

Lima Oliveira, E., Prieto Martínez, M., 2002. La Arqueoloxía en la Gasificacion de Galicia 16: Excavación del Yacimiento de Monte Buxel, Traballos de Arqueoloxía e Patrimonio 27, Laboratorio de Patrimonio. Paleoambiente e Paisaxe, Santiago de Compostela.

López-Dóriga, I., 2015. Gestión de recursos vegetales en Tongobriga: informe de la campaña 2014-2015 de excavación y muestreo arqueobotánico (Unpublished report).

López Sáez, J., Cruz, D., 2002. Orquinha dos Juncais (Vila Nova de Paiva, Viseu). Análises polínicas, Portugália. 23 pp. 5-34.

López Sáez, J., Cruz, D., Gonçalves, A., 2010. A Mamoa 1 de Madorras (Sabrosa, Vila Real, Portugal): análises polínicas e dataç̃es de Carbono 14. In: Bettencourt, A.M.S. Alves, M.I.C., Monteiro-Rodrigues, S. (Eds.), Variações Paleoambientais e Evolução Antrópica no Quaternário do Ocidente Peninsular, Associação Portuguesa para o Estudo do Quaternário-APEQ/Centro de Investigação Transdisciplinar. Cultura, Espaço e Memória-CITCEM, Braga, pp. 41-54.
López Sáez, J., López Garcia, P., Cruz, D., Canha, A., 2000. Paleovegetação e impacto humano durante a Pré-história recente na região do Alto Paiva: palinologia do povoado do Bronze final de Canedotes (Vila Nova de Paiva). Estudos Pré-históricos $8,161-185$.

López-Costas, O., Müldner, G., Martínez Cortizas, A., 2015. Diet and lifestyle in Bronze Age northwest Spain: the collective burial of Cova do Santo. J. Archaeol. Sci. 55, 209-218. López-Merino, L., Martínez Cortizas, A.M., López-Sáez, J.A., 2010. Early agriculture and palaeoenvironmental history in the north of the Iberian Peninsula: a multi-proxy analysis of the Monte Areo mire (Asturias, Spain). J. Archaeol. Sci. 37, 1978-1988.

López-Merino, L., Martínez Cortizas, A.M., López-Sáez, J.A., 2011. Human-induced changes on wetlands: a study case from NW Iberia. Quat. Sci. Rev. 30, 2745-2754.

López-Merino, L., Silva Sánchez, N., Kaal, J., López-Sáez, J.A., Martínez Cortizas, A., 2012. Post-disturbance vegetation dynamics during the Late Pleistocene and the Holocene: an example from NW Iberia. Global and Planet. Change 92-93, 58-70.

Luz, S., 2010. O Depósito de conchas do sítio arqueológico das Areias Altas (Porto, Portugal). Discussão do enquadramento arqueológico da estrutura 15. Férvedes 6, $141-145$.

Martín Seijo, M., Bettencourt, A.M.S., Abad Vidal, E., López García, J., 2012. Firewood and timber exploitation during the third and second millennia $B C$ in the northwestern Iberia: wooden resources, territories and chaîne opératoire. In: Almeida, A., Bettencourt, A., Moura, D., Monteiro-Rodrigues, S., Alves, M. (Eds.), Environmental Changes and Human Interaction Along the Western Atlantic Edge/Alterações Ambientais e Interacção Humana na Fachada Atlântica Ocidental. APEQ CEGOT, CITCEM, CCT/CGUP, Coimbra, pp. 115-135.

Martín Seijo, M., 2013. A xestión do bosque e do monte dende a Idade do Ferro á época romana no noroeste da península Ibérica: consumo de combustibles e produción de manufacturas en madeira. PhD Thesis. Departamento de Historia I, Universidade de Santiago de Compostela. Facultade de Xeografía e Historia.

Martín Seijo, M., Figueiral, I., Bettencourt, A.M.S., Gonçalves, A., Alves, M.I.C., 2011. A floresta e o mato. Exemplos da exploração dos recursos lenhosos pelas comunidades da Idade do Bronze Inicial e Médio do noroeste de Portugal. In: Tereso, J., Honrado, J., Pinto, A.T., Rego, F.C. (Eds.), Florestas do Norte de Portugal. História, Ecologia e Desafios de Gestão. InBio - Rede de Investigação em Biodiversidade e Biologia Evolutiva., Porto, pp. 85-98.

Martín-Seijo, M., Tereso, J.P., Bettencourt, A.M.S., Sampaio, H.A., Abad Vidal, E., Vidal Caeiro, L. 2015. Socio-ecology of Early and Middle Bronze Age communities in the northwest Atlantic region of Iberia: wood resources procurement and forest management. Quat. Int. http://dx.doi.org/10.1016/j.quaint.2015.08.026.

Martínez Cortizas, A., Ramil Rego, P., García Rodeja, E., Moares, C., 1993. Suelos de montaña y ciclos de estabilidad/inestabilidad en las vertientes de Galicia (NW España). In: Pérez Alberti, A., Guitián Rivera, L., Ramil Rego, P. (Eds.), La evolución del paisaje en las montañas del entorno de los Caminos Jacobeos. Xunta de Galicia, Santiago de Compostela, pp. 107-123.

Martínez-Cortizas, A., Costa-Casais, M., López-Sáez, J.A., 2009. Environmental change in NW Iberia between 7000 and 500 cal BC. Quat. Int. 200, 77-89.

Martins, M., 1990. O povoamento proto-histórico e a romanização da bacia do curso médio do Cávado. PhD Thesis. Unidade de Arqueologia da Universidade do Minho, Braga.

Méndez Fernández, F., 1994. La domesticación del paisaje durante la edad del Bronce Gallego. Trab. Prehist. 51, 77-94.

Mesquita, S., Sousa, A., 2009. Bioclimatic mapping using geostatistical approaches: application to mainland Portugal. Int. J. Climatol. 29, 2156-2170.

Mighall, T., Martínez Cortizas, A., Biester, H., Turner, S., 2006. Proxy climate and vegetation changes during the last five millennia in NW Iberia: pollen and non-pollen palynomorph data from two ombrotrophic peat bogs in the north western Iberian Peninsula. Rev. Palaeobot. Palynol. 141, 203-223.

Moreno-Larrazabal, A., Teira-Brión, A., Sopelana-Salcedo, I., Arranz-Otaegui, A., Zapata, L 2015. Ethnobotany of millet cultivation in the north of the Iberian Peninsula. 24 (4). Vegetation History and Archaeobotany, pp. 541-554.

Motuzaite-Matuzeviciute, G., Staff, R.A., Hunt, H.V., Liu, X., Jones, M.K., 2013. The early chronology of broomcorn millet (Panicum miliaceum) in Europe. Antiquity 87 (338), 1073-1085.

Muñoz Sobrino, C., 2001. Cambio climático y dinámica del paisaje en las montañas del noroeste de la península ibérica. Universidade de Santiago de Compostela, Lugo.

Muñoz Sobrino, C., García-Gil, S., Diez, J., Iglesias, J., 2007. Palynological characterization of gassy sediments in the inner part of Ría de Vigo (NW Spain). New chronological and environmental data. Geo-Mar. Lett. 27, 289-302.

Muñoz Sobrino, C., Ramil Rego, P., Gómez Orellana, L., Díaz Varela, R., 2005. Palynological data on major Holocene climatic events in NW Iberia. Boreas 34, 381-400.

Muñoz Sobrino, C., Ramil-Rego, P., Gómez-Orellana, L., 2004. Vegetation of the Lago de Sanabria Area (NW Iberia) Since the End of the Pleistocene: a Palaeoecological Reconstruction on the Basis of Two New Pollen Sequences. 13. Vegetation History and Archaeobotany, pp. 1-22

Muñoz Sobrino, C., Ramil-Rego, P., Rodríguez Guitián, M., 1997. Upland Vegetation in the North-West Iberian Peninsula after the Last Glaciation: Forest History and Deforestation Dynamics. 6. Vegetation History and Archaeobotany, pp. 215-233.

Muñoz Sobrino, C., Ramil-Rego, P., Rodríguez Guitián, M.A., 2001. Vegetation in the Mountains of Northwest Iberia During the Last Glacial-Interglacial Transition. 10. Vegetation History and Archaeobotany, pp. 7-21.

Oliveira, M., 2000. O registo paleocarpológico do NO peninsular entre o $\mathrm{III}^{\circ} \mathrm{e}$ o $\mathrm{I}^{\circ}$ milénios a.C. Contributo para o estudo da alimentação pré e proto-histórica. MSc Thesis. Universidade do Minho, Braga.

Parcero Oubiña, C., 1997. Documentación de un entorno castreño: trabajos arqueológicos en el área de Cameixa., Trabajos en Arqueología del Paisaje 1, Grupo de Investigación en Arqueología del Paisaje. Universidade de Santiago de Compostela, Santiago de Compostela. 
Parcero Oubiña, C., Ayán Vila, J., 2009. Almacenamiento, nidades domésticas y comunidades en el noroeste preromano. In: García Huerta, R., Rodríguez González, D. (Eds.), Sistemas de Almacenamiento entre los Pueblos Prerromanos peninsulares. Ediciones de la Universidad de Castilla-La Mancha, Huesca, pp. 367-422.

Peña Santos, A., 1992. Castro de Torroso (Mos, Pontevedra). Síntesis de las Memorias de las Campañas de Excavaciones 1984-1990. Xunta de Galicia, A Coruña.

Prieto Martínez, M., Juan Tresserras, J., Matamala, J., 2005. Ceramic production in the northwestern Iberian Peninsula: studying the functional features of pottery by analyzing organic material. In: Prudêncio, M., Dias, M., Waerenborgh, J. (Eds.), Understanding people through their pottery. Proocedings of the 7th European Meeting on Ancient Ceramics (EMAC'03). Ministério da Cultura/Instituto Português de Arqueologia, Lisbon, pp. 193-199.

Prieto Martínez, M., Martínez Cortizas, A., Lantes Suárez, O., Gil Agra, D., 2009. Estudio de la cerámica del yacimiento de fosas de Fraga do Zorro. In: Fonte, J. (Ed.), Actas do Congresso Transfronteiriço de Arqueologia (2008), Grupo Cultural Aqva Flaviae. 41, pp. 107-121 (Montalegre).

Primavera, M., D'Oronzo, C., Muntoni, I.M., Radina, F., Fiorentino, G., 2015. Environment, crops and harvesting strategies during the II millennium BC: resilience and adaptation in socio-economic systems of Bronze Age communities in Apulia (SE Italy). Quat. Int.

Queiroga, F., 1992. War and Castros. New approaches to the northwestern Portuguese Iron Age. PhD Thesis. University of Oxford, Oxford.

Queiroga, F., Figueiral, I., 1989. Datações de Carbono 14 para Castelo de Matos. Boletim Cultural da Câmara Municipal de Vila Nova de Famalicão 9, 67-69.

Ramil Rego, P., 1992. La vegetación cuaternaria de las Sierras Septentrionales de Lugo a través del análisis polínico. PhD Thesis. Universidade de Santiago de Compostela, Santiago de Compostela, p. 356.

Ramil Rego, P., 1993a. Paleoethnobotánica de yacimientos arqueológicos holocenos de Galicia (N.O. Cantábrico). Munibe 45, 165-174.

Ramil Rego, P., 1993b. Evolución climática e historia de la vegetación durante el Pleistoceno Superior y el Holoceno en las regiones montañosas del Noroeste Ibérico. In: Pérez, A., Guitián, L., Ramil, P. (Eds.), La evolución del paisaje en las montañas del entorno de los Caminos Jacobeos. Xunta de Galicia, Santiago de Compostela, pp. $25-60$.

Ramil Rego, P., Aira Rodríguez, M.J., 1993. A Palaeocarpological Study of Neolithic and Bronze Age Levels of the Buraco da Pala Rock-shelter (Bragança, Portugal). 2. Vegetation History and Archaeobotany, pp. 163-172.

Ramil Rego, P., Aira Rodriguez, M., Gonzalez Mendez, M., Criado Boado, F., 1990. Donnés paleobotaniques sur la presence de graines de Brassicaceae au N.O. de la Penínsule Ibérique. Rev. Paléobiol. 9, 263-272.

Ramil Rego, P., Dopazo Martínez, A., Fernández Rodríguez, C., 1996a. Cambios en las estrategias de explotación de los recursos vegetales en el Norte de la Península Ibérica. Férvedes 3, 169-187.

Ramil Rego, P., Gómez-Orellana, L., Muñoz-Sobrino, C., García-Gil, S., Iglesias, J., Pérez Martínez, M., Martínez Carreño, N., Nóvoa Fernández, B., 2009. Cambio climático y dinámica del paisaje en Galicia. Recursos Rurais 5, 21-47.

Ramil Rego, P., Muñoz-Sobrino, C., Rodríguez-Guitián, M., Gómez-Orellana, L., 1998. Differences in the vegetation of the North Iberian Peninsula during the last 16,000 years. Plant Ecol. $138,41-62$.

Ramil Rego, P., Taboada Castro, M.T., Díaz-Fierros, F., Aira, M.J., 1996b. Modificación de la cubierta vegetal y acción antrópica en la región del Minho (Norte de Portugal) durante el Holoceno. In: Ramil-Rego, P., Fernández Rodríguez, C., Rodríguez Guitían, M. (Eds.), Biogeografia Pleistocena - Holocena de la Península Ibérica. Xunta de Galicia, Santiago de Compostela, pp. 199-214.

Reimer, P.J., Bard, E., Bayliss, A., Beck, J.W., Blackwell, P.G., Bronk Ramsey, C., Buck, C.E., Cheng, H., Edwards, R.L., Friedrich, M., Grootes, P.M., Guilderson, T.P., Haflidason, H., Hajdas, I., Hatté, C., Heaton, T.J., Hoffmann, D.L., Hogg, A.G., Hughen, K.A., Kaiser, K.F., Kromer, B., Manning, S.W., Niu, M., Reimer, R.W., Richards, D.A., Scott, E.M., Southon, J.R., Staff, R.A., Turney, C.S.M., van der Plicht, J., 2013. IntCal13 and marine13 radiocarbon age calibration curves 0-50,000 years cal BP. Radiocarbon vol. 55 (4).

Rey Castiñeira, J., Martín Seijo, M., Teira Brión, A., Abad Vidal, E., Calo Ramos, N., Carballo Arceo, L., Comendador Rey, B., Picón Platas, I., Varela Montes, A., 2011. CastroBYTE. Un modelo para a xestión da información arqueolóxica. Gallaecia 30, 67-106.

Rey García, J., 2011. Guidoiro Areoso (Illa de Arousa, Pontevedra): un pequeño islote con una intensa ocupación entre el Neolítico Final y la Edad del Bronce. In: PrietoMartínez, M., Salanova, L. (Eds.), Las comunidades campaniformes en Galicia. Cambios sociales en el III y II milenios BC en el NW de la Península Ibérica, Diputación de Pontevedra, Pontevedra, pp. 201-210.
Rodríguez Guitián, M., Ramil-Rego, P., 2007. Clasificaciones climáticas aplicadas a Galicia: revisión desde una perspectiva biogeográfica. Recursos Rurais 1, 31-53.

Rodríguez Saiz, E., 2010. Intervención arqueolóxica previa á posta en valor do xacemento de Monte das Cabanas. Campus Universitario Lagoas-Marcosende, Vigo (Unpublished report).

Rubinos Pérez, A., 2001. Fechas de Carbono - 14 del yacimiento de Santinha, Amares, Braga. In: Bettencourt, A.M.S. (Ed.), O Povoado da Santinha, Amares, Norte de Portugal, nos Finais da Idade do Bronze, Cadernos de Arqueologia - Monografias, 12. Universidade de Arqueologia/Instituto de Ciências Sociais, Braga, pp. 75-78.

Sampaio, H.A., 2014. A Idade do Bronze na bacia do rio Ave (Noroeste de Portugal). PhD Thesis. Universidade do Minho, Braga.

Sanches, M.J., 1988. O povoado da Lavra (Marco de Canaveses). Arqueologia 17, 125-134

Sanches, M.J., 1995. O povoado da Lavra, serra da Aboboreira. In: Cordeiro, I., Silva, I. Fernandes, M. (Eds.), A Idade do Bronze em Portugal. Discursos de Poder, S.E.C., Lisboa, p. 116.

Sanches, M.J., 1997. Pré-história Recente de Trás-os-Montes e Alto Douro, Sociedade Portuguesa de Antropologia e. Etnologia, Porto.

Sanches, M.J., 2008. O Crasto de Palheiros. Fragada do Crasto. Murça - Portugal, Munícipio de Murça, Murça.

Sanches, M.J., Nunes, S., Pinto, D., 2007. Trás-os-Montes (Norte de Portugal) - As gentes e os ecossistemas, do Neolítico à Idade do Ferro. In: Jorge, S., Bettencourt, A.M.S. Figueiral, I. (Eds.), A Concepção das paisagens e dos espaços na Arqueologia da Península Ibérica, Actas do IV Congresso de Arqueologia Peninsular (2004), Promontoria Monográfica 8. Universidade do Algarve, Faro, pp. 189-206.

Sarmento, F., 1903. Materiaes para a archeologia do concelho de Guimarães. Revista de Guimarães 20, 5-16.

Sampaio, H.A., Bettencourt, A.M.S., Barbosa, R., Dinis, A., Cruz, C., 2008. A importância do povoado do Pego no Bronze Final do Noroeste de Portugal. Férvedes 5, 227-233.

Seabra, L., 2015. Estudo Paleoetnobotânico do Povoado da Idade do Ferro do Crastoeiro (Noroeste de Portugal), MSc thesis. Universidade do Minho, Braga.

Sigaut, F., 1988. A method for identifying grain storage techniques and its application for European agricultural history. Tools Tillage 6 (1), 3.

Silva, A.C.D., 1986. A Cultura Castreja do Noroeste de Portugal, Museu Arqueológico da Citânia de. Sanfins, Paços de Ferreira.

Silva, A.C.F., Silva, C.T., Lopes, A.B., 1984. Depósito de fundidor do final da idade do bronze do Castro da Senhora da Guia: (Baiões, S. Pedro do Sul, Viseu), Colectânea de Estudos de Homenagem a D. Domingos de Pinho Brandão. pp. 73-95.

Silva, C.T., 1979. O Castro de Baiões (S. Pedro do Sul). Beira Alta 38, 510-531.

Silva, M.M.O.S., 2000. Recipientes cerâmicos do Bronze Final dos povoados de Castelo de Aguiar (Vila Pouca de Aguiar) e da Lavra (Marco de Canaveses): seu enquadramento regional, MSc thesis. Universidade do Porto, Porto.

Stika, H.-P., Heiss, A.G., 2013. Plant Cultivation in the Bronze Age. Chapter 19. In: Fokkens, H., Harding, A. (Eds.), The Oxford Handbook of the European Bronze Age. Oxford University Press, Oxford, pp. 348-369.

Téllez, R., Chamorro, J., Arnanz, A., 1990. Análisis discriminante en la identificación de trigos arqueológicos españoles. Trab. Prehist. 47, 291-318.

Tereso, J.P., 2012. Environmental change, agricultural development and social trends in NW Iberia from the late prehistory to the late antiquity. PhD Thesis. Biology Department, Faculty of Sciences, University of Porto, Porto.

Tereso, J.P., Ramil-Rego, P., Álvarez González, Y., López González, L., Almeida-da-Silva, R 2013. Massive storage in As Laias/O Castelo (Ourense, NW Spain) from the Late Bronze Age/Iron Age transition to the Roman period: a palaeoethnobotanical approach. J. Archaeol. Sci. 40, 3865-3877.

van Mourik, J., 1986. Pollen profiles of slope deposits in the Galician area (N.W. Spain) Ned. Geogr. Stud. 12, 1-171.

Vázquez Varela, J.M., 1993-1994. El cultivo del mijo, (Panicum miliaceum L.) en la cultura castreña del. Noroeste de la Península Ibérica, Cuadernos de Estudios Gallegos. 41 (106), 65-73.

Vieira, A., 2014. Alguns dados para o estudo da Idade do Bronze no Norte de Portugal, A Idade do Bronze em Portugal: os dados e problemas. Antrope - Série Monográfica 1. Instituto Politécnico de Tomar, pp. 52-101.

Vilaseco Vázquez, X.I., 2012. Os Pericos (Ribeira, A Coruña). Bronce Final e segunda Idade do Ferro no extremo meridional da península do Barbanza. In: Fábregas Valcarce, R. Rodríguez Rellán, C. (Eds.), A Arte Rupestre no Norte do Barbanza. Andavira Editora, Santiago de Compostela, pp. 137-150.

Walker, B., Gunderson, L., Kinzig, A., Folke, C., Carpenter, S., Schultz, L., 2006. A handful of heuristics and some propositions for understanding resilience in social-ecological systems. Ecol. Soc. 11 (1), 13. 